\title{
Revision of the oryctocephalid trilobite genera Arthricocephalus Bergeron and Oryctocarella Tomashpolskaya and Karpinski (Cambrian) from South China and Siberia
}

\author{
Shanchi Peng, ${ }^{1}$ Loren E. Babcock, ${ }^{2}$ Xuejian Zhu, ${ }^{1}$ Qianping Lei, ${ }^{3}$ and Tao Dai ${ }^{4}$ \\ ${ }^{1}$ State Key Laboratory of Palaeobiology and Stratigraphy, Nanjing Institute of Geology and Palaeontology, Chinese Academy of Sciences, 39 East \\ Beijing Road, Nanjing, 210008 China 〈scpeng@nigpas.ac.cn〉; 〈xjzhu@nigpas.ac.cn〉 \\ ${ }^{2}$ School of Earth Sciences, The Ohio State University, 125 South Oval Mall, Columbus, OH 43210, USA 〈babcockloren@ gmail.com〉 \\ ${ }^{3}$ Academic Research Department, Changzhou Museum, No. 1288 Longcheng Road, Changzhou 213022, China 〈cicelyapple@126.com〉 \\ ${ }^{4}$ State Key Laboratory for Continental Dynamics, and Department of Geology, Northwest University, Xi'an 710069, China 〈daitao@nwu.edu.cn〉
}

\begin{abstract}
Restudy of the limestone slab containing the type suite of Arthricocephalus chauveaui Bergeron, 1899 (Trilobita), the type species of Arthricocephalus Bergeron, 1899, shows that specimens of three species, each representing a separate genus, are present on the slab and were likely included in the original concept of the species. Besides A. chauveaui, the slab contains specimens of Oryctocarella duyunensis (Qian, 1961) and Duyunaspis duyunensis Zhang and Qian in Zhou et al., 1977. Bergeron (1899) illustrated one exoskeleton from the type suite of A. chauveaui only and apparently based much of his written description on that specimen. This specimen was clearly intended to be the type specimen of A. chauveaui. Subsequently, Lane et al. (1988) designated another specimen, which was not originally illustrated, as the lectotype, and this specimen is referable to Oryctocarella duyunensis. As revised here, Bergeron's illustrated specimen should be regarded as the lectotype of A. chauveaui. Such designation stabilizes the concepts of both Arthricocephalus and A. chauveaui. Arthricocephalites Qian in Lu et al., 1974 and Haliplanktos Blaker and Peel, 1997 are regarded as junior synonyms of Arthricocephalus. Oryctocarella Tomashpolskaya and Karpinski, 1961, which was previously regarded as a junior synonym of Arthricocephalus, is revived as a valid genus. Oryctocarella includes a number of species previously assigned to Arthricocephalus. The type species of both Arthricocephalus and Oryctocarella, together with related species, are described on the basis of new material.
\end{abstract}

\section{Introduction}

Orycrocephalid trilobites play an important role in Cambrian chronostratigraphy because of their relatively wide geographic distributions. The first appearance datum (FAD) of Oryctocephalus indicus (Reed, 1910) has been proposed as the primary tool for recognizing the conterminous base of Cambrian Series 3 and Stage 5 (Zhao et al., 2001b, 2004; Peng et al., 2012), and the FAD of another orytocephalid, Ovatoryctocara granulata (Chernysheva, 1962), is used as another intercontinental tie point below the base of Stage 5, which has been proposed as an alternative level to define the conterminous base of Series 3 and Stage 5 (Fletcher, 2003; Shabanov et al., 2008). The base of the Duyunian Stage, a regional stage used for South China, is marked by the FAD of the oryctocephalid Arthricocephalus chauveaui (Peng, 2000). However, the concepts of Arthricocephalus and its type species $A$. chauveaui have long been unsettled, as discussed herein. Confusion in the concept of A. chauveaui was introduced by the fallacious designation of a lectotype (Lane et al., 1988) that was not illustrated in the original publication (Bergeron, 1899), and which is shown here to belong to another oryctocephalid species. Poor understanding of the generic concept of
Arthricocephalus lead not only to suppression of the genus Oryctocarella as a junior synonym of Arthricocephalus (Suvorova, 1964), but also to incorrect assignment of Oryctocarella specimens to Arthricocephalus (e.g., Qian, 1961; Lu and Qian, 1964; Qian and Lin in Zhou et al., 1977; Yin in Yin and Li, 1978; Zhang et al., 1980; Zhang and Zhou, 1985; Blaker and Peel, 1977; Yuan et al., 2002; McNamara et al., 2003; Peng et al., 2005a, 2006), and to erection of new genera having concepts identical with Arthricocephalus.

This article clarifies the generic concepts of Arthricocephalus and Oryctocarella, prompted by a restudy of the original type series of Arthricocephalus chauveaui, the type species of Arthricocephalus. In addition, topotypic material of Oryctocarella sibirica, the type species of Oryctocarella, has been collected and studied, leading to further elucidation of the concept of this monospecific genus.

\section{Revised concept of Arthricocephalus}

Bergeron (1899) erected Arthricocephalus, with A. chauveaui Bergeron, 1899 as the type species by monotypy. Bergeron $(1899$, p. 514) stated that the genus and the type species were 


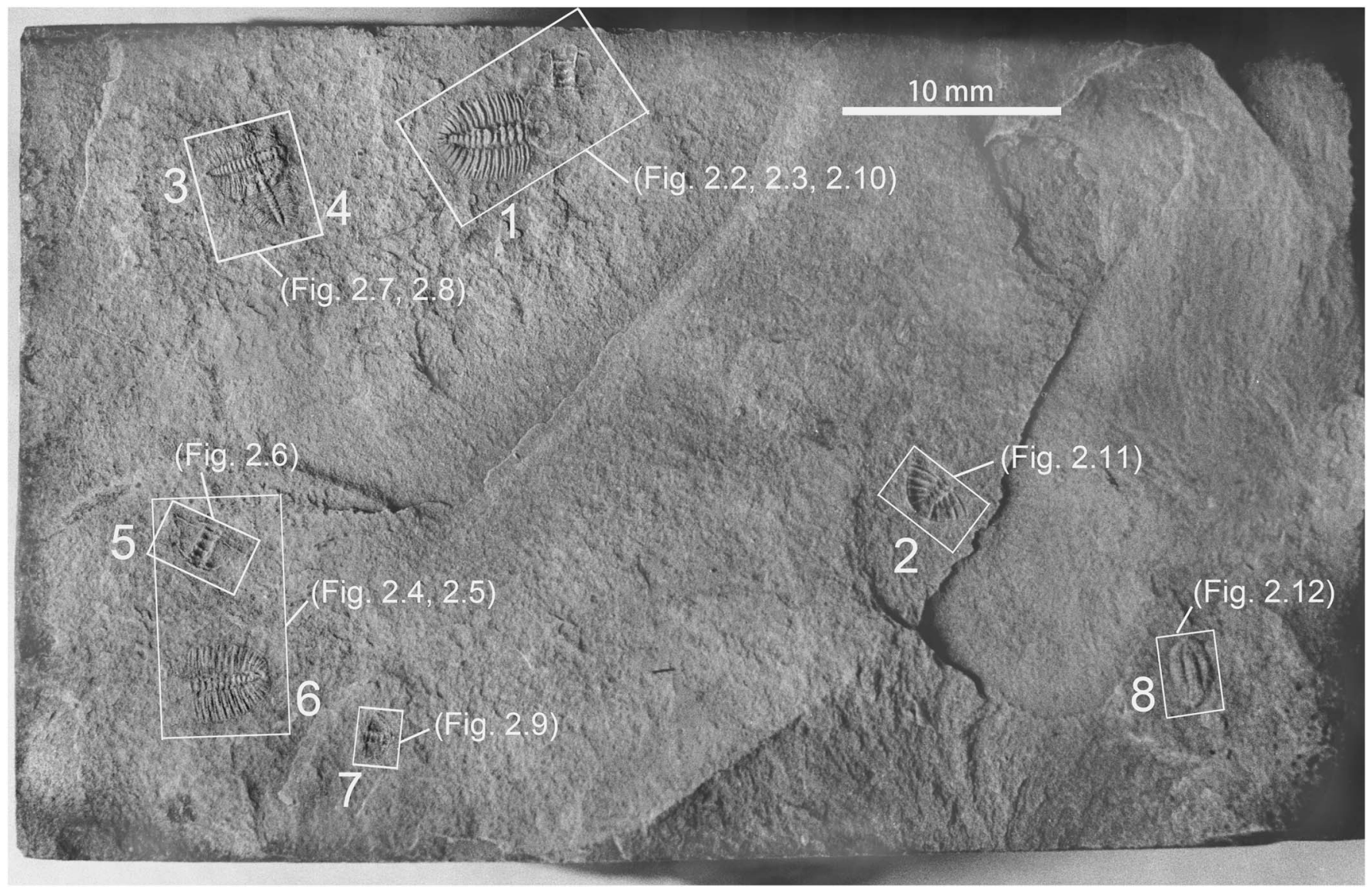

Figure 1. Slab with the type series of Arthricocephalus chauveaui Bergeron, 1899, reassigned to three species, each in a separate genus; from the Balang Formation, north of Tongren, eastern Guizhou, China. Museum of the Geological Department, Claude Bernard University, Lyon, France, E.M. 90001. Sclerites (1-6, 8) were renumbered as E.M. 90001a-g by Lane et al. (1988). An external mold of incomplete cephalon (7) was not previously illustrated and now numbered E.M. 90001h. (1-2) Arthricocephalus chauveaui Bergeron, 1899: (1) disarticulated holaspid exoskeleton; (2) external mold of holaspid pygidium. (3-7) Oryctocarella duyunensis (Qian, 1961): $(\mathbf{3}, \mathbf{4})$ two meraspid exoskeletons; $(\mathbf{5})$ external mold of cranidium; (6) thoracopygon; (7) external mold of incomplete cephalon. (8) Duyunaspis duyunensis Zhang and Qian in Zhou et al., 1977, meraspid exoskeleton. See also caption of Figure 2 for detailed description of each specimen. Scale bar $=10 \mathrm{~mm}$.

based on 10 sclerites preserved on the bedding surface of a small slab of limestone (Fig. 1). The slab is composed of lime mudstone, and measures $6.2 \mathrm{~cm}$ by $3.8 \mathrm{~cm}$. It was collected from the Balang Formation, north of Tongren, eastern Guizhou, South China, and sent to France by M. Chauveau for study by Bergeron. The sclerites on the slab include five exoskeletons in varying degress of articulation, a small external mold of an incomplete meraspid cephalon, and an external mold of a holaspid pygidium (Figs. 1, 2.1-2.12). Bergeron (1899) evidently considered the specimens to be conspecific, and used all of them to establish the morphologic limits of $A$. chauveaui. The original publication included one illustrated specimen, a dorsal exoskeleton lacking the free cheeks (reproduced here as Fig. 2.1).

Bergeron's (1899) original concept of A. chauveaui was generally accepted by subsequent authors including Lane et al. (1988), Blaker and Peel (1997), and McNamara et al. (2003). Lane et al. (1988) regarded all of the sclerites present on

Figure 2. Original illustration (1) and type series (2-12) of Arthricocephalus chauveaui Bergeron, 1899, from the Balang Formation, north of Tongren, eastern Guizhou, China; all sclerites are on a single slab, all in dorsal view unless stated otherwise. White arrowhead indicates posterior margin of thorax; arrowhead with black outline indicates the posterior margin of partially released segment of transitory pygidium; black triangles indicate posteromedial notch on pygidial border; b = border, c = connective suture, $\mathrm{d}=$ doublure. $(\mathbf{1 - 3}, \mathbf{1 0}, \mathbf{1 1})$ Arthricocephalus chauveaui Bergeron, 1899: (1) line-drawing of exoskeleton, illustrated as fig. 9 in Bergeron (1899); (2) E.M. 90001a, type specimen, designated as lectotype, disarticulated holaspid exoskeleton with inverted cranidium, librigena and rostral-hypostomal plate; (3) reversal of image in $\mathbf{2}$ (lectotype), from negative film; (10) latex cast from external mold of rostral-hypostomal plate and cephalic doublure of specimen in $\mathbf{2}$ and $\mathbf{3}$ (lectotype), ventral view; (11) E.M. 90001g, latex cast of external mold of pygidium; dark curved region at margin is the mold of the pygidial doublure; part of the upturned border is preserved at left upper corner of pygidium. (4-9) Oryctocarella duyunensis (Qian, 1961), specimens determined by Lane et al. (1988) as A. chauveaui: (4) E.M. 90001c, disarticulated thoracopygon, posterior margin of thorax uncertain (arrows indicate alternative possibilities); specimen may be meraspid degree 10 or early holaspid (11 segments); (5) E.M. 90001b, inverted cranidium, external mold in ventral view, illustrated and designated as the lectotype of Arthricocephalus chauveaui by Lane et al. (1988, pl.1, fig. 2); (6) latex cast from external mold of cranidium in 5; $(\mathbf{7}, \mathbf{8})$ two meraspid exoskeletons lacking librigenae: (7) E.M. 90001d, meraspid degree 9; (8) E.M. 90001e, meraspid degree 8; (9) E.M. 90001h, latex cast of external mold of incomplete meraspid cephalon in Figure 1.7. (12) Duyunaspis duyunensis Zhang and Qian in Zhou et al., 1977: E.M. 90001f, meraspid exoskeleton, specimen identified as meraspid degree 5 or 6 of A. chauveaui by Lane et al. (1988). All scale bars represent $1.0 \mathrm{~mm}$. 
Bergeron's slab (Fig. 1) as syntypes and illustrated nearly all of them photographically. They selected one cranidium (Figs. 1.5, $2.5,2.6)$ as the lectotype of $A$. chauveaui and regarded all other specimens except for a small cranidium (Figs. 1.7, 2.9) on the slab (Figs. 1.1-1.4, 1.6, 1.8, 2.4, 2.7, 2.8, 2.11, 2.12) as paralectotypes. The specimen selected by Lane et al. (1988) as the lectotype is not the specimen originally illustrated as a line drawing by Bergeron (1899, fig. 9; reproduced here as Fig. 2.1).

Restudy of the material on Bergeron's slab shows that three species are present, each referable to a separate genus (Figs. 1,2). The exoskeleton and only specimen illustrated by Bergeron (1899, fig. 9; Fig. 2.1) can be inferred to be the
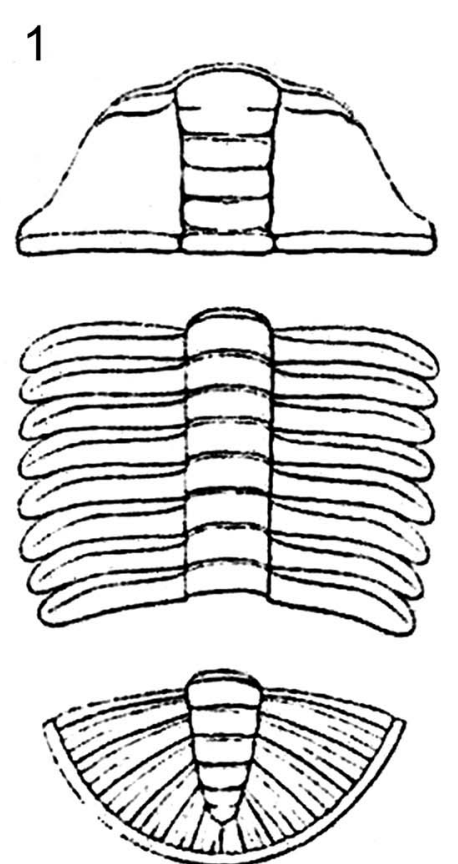
Fig. 9. - Arthricocephalus
Chauveaui n. g., n. sp.
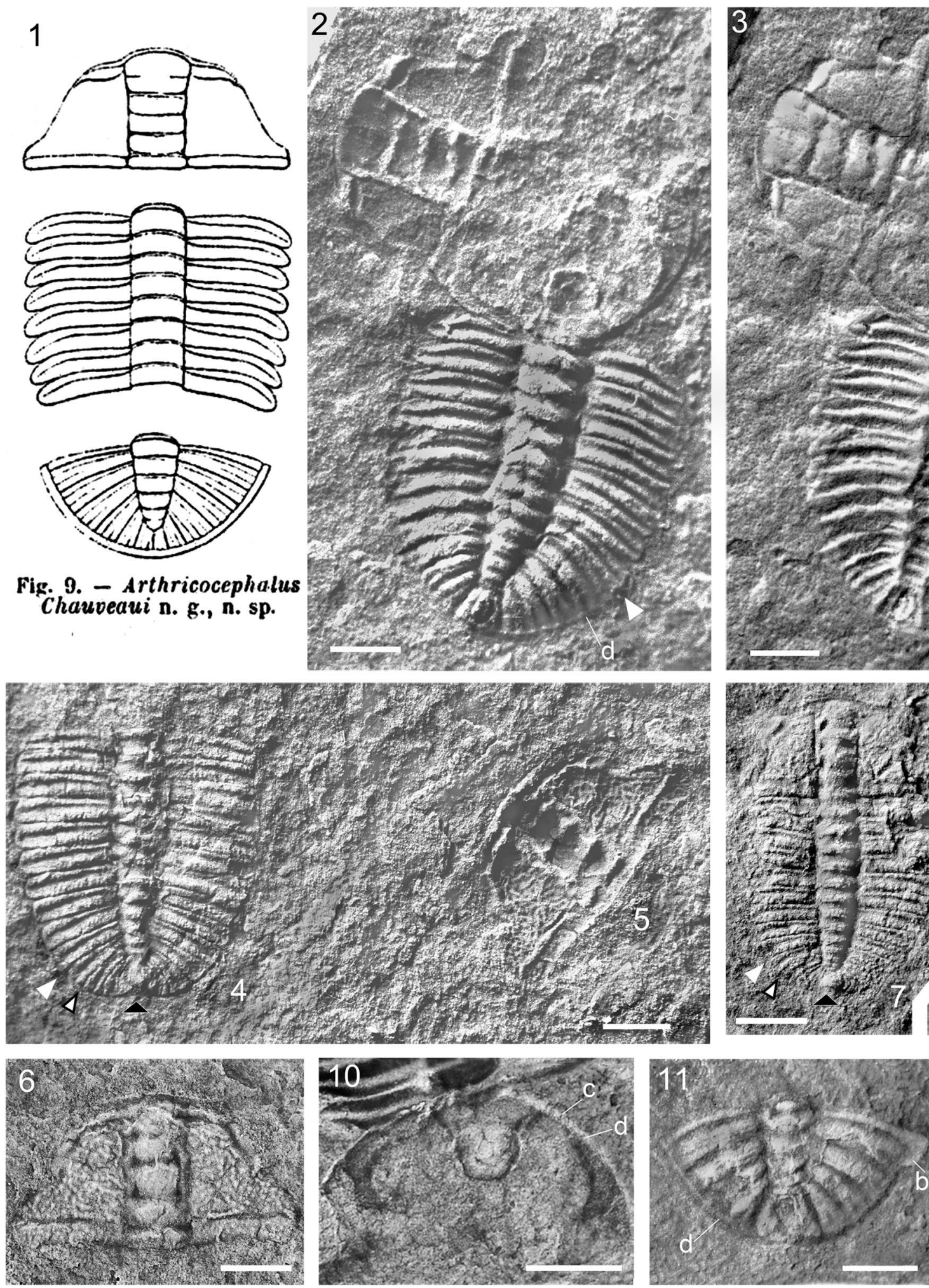
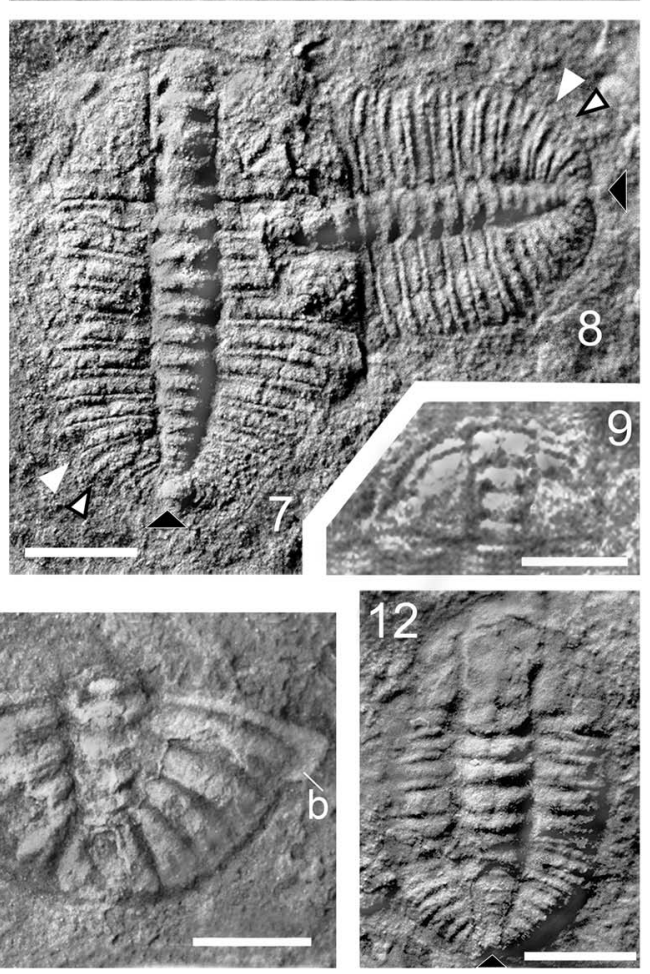
intended type specimen (a lectotype by ICZN convention). The cranidium selected by Lane et al. (1988) as the lectotype (Figs. 1.5, 2.5, 2.6), by contrast, belongs to Oryctocarella duyunensis. The designating of this specimen by Lane et al. (1988) created confusion about the generic concept because most authors seem to have relied on Bergeron's line drawing for guidance on the species and generic concepts.

Photographs of Bergeron's (1899) specimens published by Lane et al. (1988, pl. 1, figs.1-5) as A. chauveaui show great morphologic differences among the sclerites in the type series, suggesting different species are included. Bergeron's slab was not re-examined in the preparation of the 1988 paper (P.D. Lane, personal communication, 2016). In 2002, SP examined the type material of Arthricocephalus chauveaui at the museum of the Geological Department, Claude Bernard University, Lyon, France, and rephotographed all exposed sclerites. The examination demonstrated that Bergeron's line drawing of A. chauveaui (Fig. 2.1) is generally accurate, as concluded by Lane et al. (1988, p. 558). The examination also indicated that the line drawing was based principally on the largest exoskeleton on the slab. That specimen (Fig. 2.2, 2.3, 2.10) is easily identifiable among the sclerites on the slab. The specimen that evidently served as the basis for the illustration and much of the original description (Bergeron, 1899) is an exuvium of the exoskeleton having the cranidium, librigenae, and hypostome disarticulated from the thoracopygon and overturned (Figs. 1.1, $2.2,2.3,2.10$ ). Features showing that the exoskeleton is the basis for Bergeron's illustration and description include: (1) outline of glabella, which is pestle-shaped, expanded forward anterior to the $\mathrm{S} 3$ furrow, and defined laterally by curved axial furrows; (2) nature of the posterior three glabella furrows (S1-S3), which are transversely continuous across the glabella and reach to the axial furrows; (3) shape of the posterior three glabellar lobes (L1-L3), which are narrow, subrectangular, about three times wider than long, and subequal in length; (4) length of the "anterior lobe" of the glabella (formed by fusion of L4 and the frontal lobe), which is twice as long as L3; (5) segmentation pattern of the thorax, with eight segments, the posteriormost of which is incompletely released; (6) semicircular outline of the pygidium (subequal to the cranidium in length); (7) segmentation of the pygidial axis (five rings and a terminal piece); (8) faint interpleural furrows of the pygidium; and (9) smooth, continuous arc forming the posterior margin of the pygidium.

Bergeron's (1899) original description of A. chauveaui provides further evidence that the species' description was principally based on the largest exoskeleton on the slab. Characters noted by Bergeron include: (1) expansion in width of the anterior glabellar lobe and expansion of its length to twice that of the other lobes, implying the glabella is expanded forward anterior to S3; (2) eight thoracic rings (segments); (3) six rings in the pygidial axis; (4) cranidial length of $2.5 \mathrm{~mm}$; and (5) pygidial length of $2.5 \mathrm{~mm}$. None of the other exoskeletons present on the slab has this combination of characters. The sum of information published by Bergeron (1899) indicates that the largest exoskeleton on the original limestone slab was the basis for most of the species description and for the illustration, and it is inferred that this exoskeleton was the intended type specimen.

Examination of Bergeron's type exoskeleton reveals some misinterpretation of features in the original illustration
(Bergeron, 1899, fig. 9). The ridge-like structure along the pygidial border as illustrated is actually the ventral doublure (compare Fig. 2.1, 2.11). This misinterpretation may have been influenced in part by the appearance of the largest pygidium on the slab (Fig. 1.2), which is preserved as an external mold. The latex cast of the pygidial external mold reveals that the "ridge" is the ventral doublure (Fig. 2.11). This pygidium is the only sclerite on Bergeron's (1899) slab that is conspecific with the largest exoskeleton. Fulcra and facets on the thoracic segments were not illustrated by Bergeron (1899), although they are present. The fulcra and facets are not well exposed on the type specimen, and are not presented on the other thoracic material on the slab except for the smallest exoskeleton (Fig. 2.12).

Apart from the specimen illustrated here in Figure 2.2 and 2.3, there are four additional exoskeletons on Bergeron's slab (E.M. 90001c [thoracopygon associated with cranidium, 90001b], 90001d, 90001e, 90001f), but none of them matches the original illustration and description. A number of differences between these exoskeletons and the largest exoskeleton on the slab (E.M. 90001a) indicate that they are not the specimens on which Bergeron's illustration was based, and that they are neither conspecific nor congeneric with $A$. chauveaui. Three exoskeletons (E.M. 90001b and 90001c, 90001d, 90001e; Figs. 1.3-1.6, 2.4-2.8) are reassigned herein to Oryctocarella duyunensis (Qian, 1961). New, abundant and well-preserved material from the Balang Formation helps to clarify the differences between A. chauveaui and O. duyunensis (Fig. 3), and each of the distinguishing characteristics of $O$. duyunensis is present on the three sub-largest exoskeletons of Bergeron's slab. These exoskeletons differ from A. chauveaui in: (1) having a narrow cylindrical glabella that is parallel-sided and defined laterally by straight axial furrows; (2) having pit-like glabellar furrows that are isolated from the axial furrows and two or three pairs of furrows (S1, S2, S3) connected transversely by furrows, but not extending abaxially to the axial furrows; (3) having straight rather than curved axial furrows; (4) having proportionally long L1-L3 and a short "anterior lobe" (L4 plus frontal lobe, nearly as long as L3); (5) having an upturned rather than ridge-like cranidial border; (6) having palpebral lobes in a relatively anterior position; (7) having an ocular ridge relatively closer to the anterior border furrow; (8) having a thorax with more than eight segments (up to 10 or 11; Fig. 2.4); (9) having a smaller pygidium that is shorter than the cephalon; (10) having a pygidial axis with three rather than five axial rings; (11) having well-defined interpleural furrows; (12) having a medial notch at the posterior margin of the pygidium; and (13) lacking a pygidial border rather than having an upturned border (Figs. 2.4, 2.7-2.8, 3.2). The thoraxes in each of these three exoskeletons are apparently non-fulcrate, differing in this character from the fulcrate thorax with geniculate segments of the largest exoskeleton. This difference was suggested by Whittington (1995, p. 555) who found that the "weakly geniculated pleurae" described by Lane et al. (1988, p. 559) for A. chauveaui are not present on some specimens assigned to Arthricocephalus by Zhang et al. (1980). Cephala on each of the three sub-largest exoskeletons appear to have proparian facial sutures, whereas on E.M. 90001a the sutures are gonatoparian.

The smallest exoskeleton on Bergeron's (1899) slab (E.M. 90001f, Figs. 1.8, 2.12) also is not conspecific with A. chauveaui 


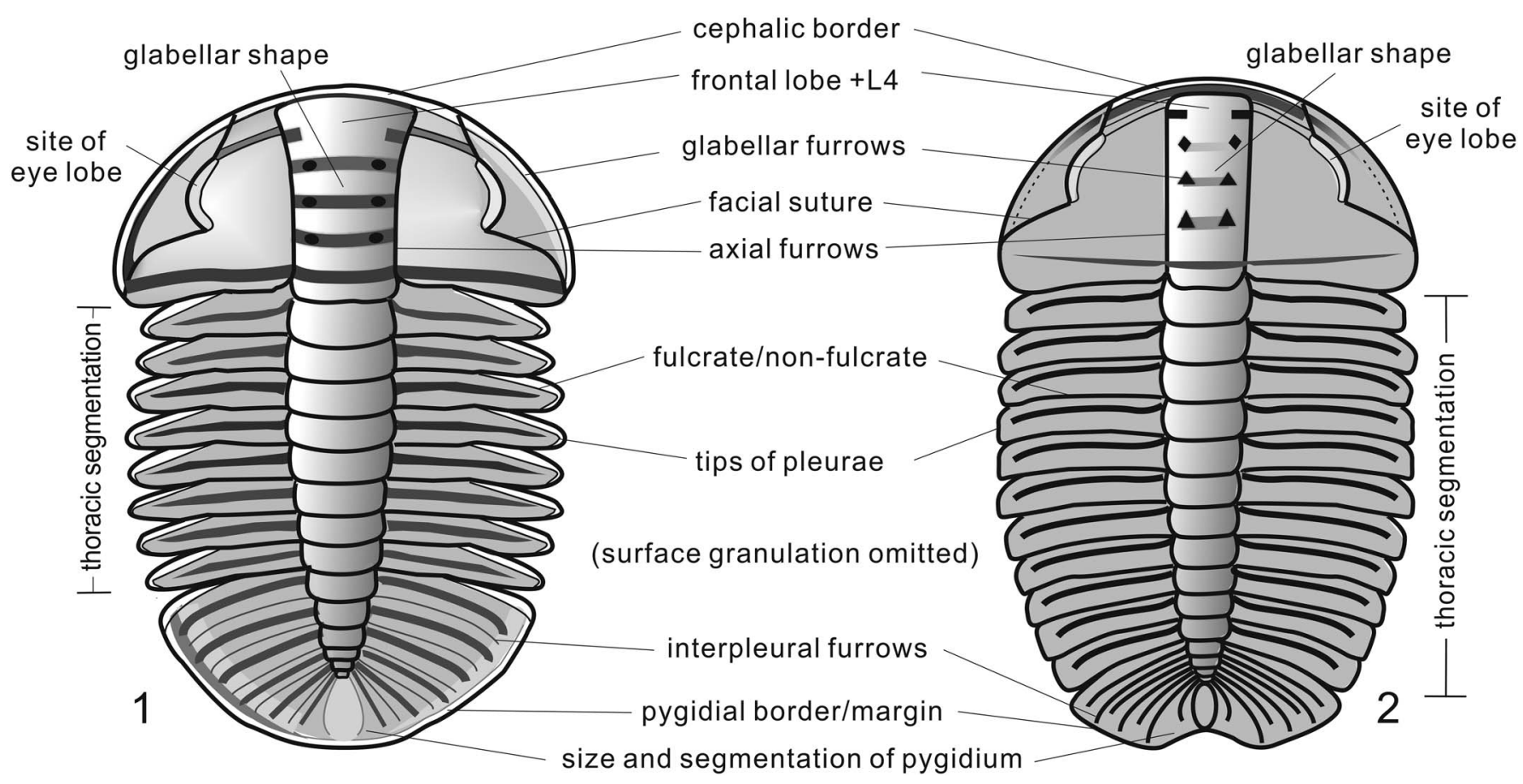

Figure 3. Reconstructions of Arthricocephalus chauveaui (1) based on NIGP 163354, and Oryctocarella duyunensis (2) based on NWU-DYXJT 1823, both from the Balang Formation of western Hunan, China. These species show differences in glabellar outline (forwardly expanding or pestle-shaped, 1, compared to cylindrical, 2); development of the glabellar furrows (transglabellar, 1, compared to pit-like, 2); course of the axial furrow (curved, 1, compared to straight, 2); course of the facial suture (gonatoparian, 1, compared to proparian, 2); shape of the anterior cranidial border (upturned posterolaterally, 1, compared to anteriorly, 2); position of the palpebral lobe (situated at the level of the glabellar mid-point, 1, compared to located anteriorly, 2); presence,1, or absence, 2, of fulcra; thoracic segmentation (eight segments, 1, rather than 11 segments, 2); tips of pleurae (pointed, 1, rather than slightly rounded, 2); size and segmentation of pygidium (isopygous, with five pleurae, 1, compared to micropygous, with three pleurae, 2); pygidial interpleural furrows (faint, $\mathbf{1}$, rather than well defined, 2); pygidial border (upturned, 1, rather than absent, 2); development of the posterior pygidial margin (equally curved, 1, rather than with a median notch, 2); and surface prosopon (smooth to finely granulose, 1, as compared to coarsely and densely granulose, 2; surface granulation on the reconstruction of each species has been omitted).

although it has long been considered to be a meraspid of this species (e.g., Lane et al., 1988; Blaker and Peel, 1997; McNamara et al., 2003). The specimen also differs considerably from specimens on Bergeron's (1899) slab reassigned to Oryctocarella duyunensis. The specimen is here reassigned to Duyunaspis duyunensis Zhang and Qian in Zhou et al., 1977 (p. 132, pl. 41, figs. 5, 6), the type species of Duyunaspis. The exoskeleton differs from both $A$. chauveaui and $O$. duyunensis in having a proportionally large glabella that is wider than the fixigena; shallow and weakly impressed glabellar furrows; a proportionally wide thoracic axis that is nearly as wide as the pleural area; and a relatively small pygidium with a broad axis. The specimen of D. duyunensis has a medial notch on the posterior margin of the pygidium, similar to $O$. duyunensis, but the pygidial axis in specimens of $O$. duyunensis is much narrower, being only about half as wide as the pleural area. The thorax of the smallest exoskeleton on Bergeron's slab has fulcrate segments, similar to A. chauveaui, but the fulcra in the smallest specimen lie much closer to axial furrow than they do in the largest exoskeleton.

We conclude that Bergeron's (1899) original illustration and description of $A$. chauveaui are based principally on the largest exoskeleton in the type series. According to Article 74.6.1 of the International Code of Zoological Nomenclature (ICZN, 1999), which states that "The inference that the specimen is a 'holotype' or 'the type' may be by reference to an illustration or description of specimen," the largest exoskeleton on Bergeron's slab is inferred as 'type' of A. chauveaui.
In accordance with Article 74.6, "the assumption that the species-group taxon was based upon a single type specimen is deemed to have designated that specimen as the lectotype." For these reasons, the largest exoskeleton on Bergeron's (1899) limestone slab (E.M. 90001a) is designed the lectotype of Arthricocephalus chauveaui. Arthricocephalus is considered to be a monotypic genus.

An external mold of a large pygidium (E.M. 90001g; Figs. 1.2, 2.11) on Bergeron's (1899) slab remains assigned to Arthricocephalus chauveaui; it is a paralectotype. Other sclerites on the slab, which are presumed to be part of Bergeron's suite of examined specimens and all originally referred to A. chauveaui, are also considered to be paralectotypes of A. chauveaui. All of these specimens, however, are here reassigned as either Oryctocarella duyunensis (E.M. 90001b90001e, 90001h) or Duyunaspis duyunensis (E.M. 90001f).

\section{Incorrect designation of lectotype}

Circumstances surrounding the designation of a lectotype of Arthricocephalus chauveaui by Lane et al. (1988), and subsequent treatment of Bergeron's (1899) suite of material, has resulted in ambiguity of the concepts of both A. chauveaui Bergeron, 1899 and Arthricocephalus Bergeron, 1899. Photographs of some Bergeron's sclerites were first published by Lane et al. (1988). In that same article, Lane et al. (1988, p. 558) stated that they accepted the specimen upon which 
Bergeron's line drawing was based (Bergeron, 1899, fig. 9) as the lectotype of the species because it was the only illustration Bergeron published of $A$. chauveaui. As originally published (Bergeron 1899, fig. 9; reproduced herein as Fig. 2.1), the exoskeleton was separated into three parts-cranidium, thorax, and pygidium - but examination of the limestone slab makes it clear that the illustration is of an exoskeleton separated into a thoracopygon with an associated, inverted cranidium (Fig. 2.2, 2.3). Bergeron's (1899) description also seems to apply to this specimen. Because the individual specimen on which most of Bergeron's (1899) original published information was based can be identified from the original slab of examined material, there can be little doubt that it was the intended 'type,' and by implication should be the lectotype of the species.

Lane et al. (1988) seem to have followed this line of reasoning, but a mixup evidently occurred at publication stage, leading to designation of an inverted cranidium, E.M. 90001b (Fig. 2.5, 2.6) as the lectotype of Arthricocephalus chauveaui. That specimen is here reassigned to Oryctocarella duyunensis (Qian, 1961). The article by Lane et al. (1988) was published in Chinese and English, and the Chinese portion of the paper was translated from a draft originally written in English. In the English description, Lane et al. (1988) clearly referred to the exoskeleton (E.M. 90001a) rather than the cranidium (E.M. 90001b) as the specimen selected to be the lectotype. As described (Lane et al., 1988, p. 559), the cranidium has a "subrectangular glabella" (not a cylindrical glabella as present in E.M. 90001b) and "four pairs of deep glabellar pits, S1-S3 reaching to axial furrows and connected across glabella also connected across glabella by shallow transverse furrow" (not isolated from the axial furrows); the thorax has "pleurae with weak as geniculation" (i.e., segments are fulcrate rather than non-fulcrate, implying the presence of thoracic facets). As discussed above, the only exoskeleton in Bergeron's (1899) suite of examined specimens that meets all these criteria is E.M. $90001 \mathrm{a}$

In the Chinese translation, the discussion related to the designation of the specimen in Bergeron's (1899) figure 9 as the lectotype, and the description of the glabellar furrows meeting the axial furrows, were omitted. According to P.D. Lane (written communication, 2016), designation of a lectotype was somehow changed from that in the draft, without his knowledge, both in the description and plate explanation. As published, a cranidium, E.M. 90001b, was indicated as the lectotype (Lane et al., 1988, p. 555, 558, 559, pl. 1, right in fig. 2; herein, Figs. 1.5, 2.5, 2.6). The Chinese part of the article was published prior to the English portion, and the altered designation of lectotype, which was at odds with the written morphological description published later in English, was included in it. Repetition of this designation at the time when the English portion of the article was published exacerbated the problem.

Because the cranidium (E.M. 90001b) was erroneously selected as the lectotype of Arthricocephalus chauveaui, but in fact belongs to Oryctocarella duyunensis, it has been the source of some misinterpretation of the concepts of both Arthricocephalus and A. chauveaui. Blaker and Peel (1997, p. 110, fig. 62.1) and Geyer (2005, fig. 3) interpreted the largest exoskeleton on Bergeron's (1899) slab (E.M. 90001a) as the basis for Bergeron's (1899) illustration, indicating it as the lectotype of the species, and discussed the concept of A. chauveaui in light of that view. M.R. Blaker was a co-author of the Lane et al. (1988) paper, and his 1997 monograph (Blaker and Peel, 1997) showed that he did not realize there had been a change in the designation of a lectotype for $A$. chauveaui.

Yuan et al. (2002, p. 120) and McNamara et al. (2003, p. 107) accepted the cranidium (E.M. 90001b) with its associated thoracopygon (E.M. 90001c) to be the lectotype and discussed a different concept of Arthricocephalus chauveaui. The cranidium and its associated thoracopygon may originate from a single individual, but Lane et al. (1988, p. 555, 559) definitely specified the cranidium to be the lectotype. This thoracopygon differs considerably from the thorax and pygidium illustrated by Bergeron (1899, fig. 9; = E.M. 90001a). The differences from Bergeron's illustrated specimen include a greater number of thoracic segments, non-fulcrate segments, and a pygidium that is shorter and less segmented. The species concept discussed by Yuan et al. (2002, p. 120) and McNamara et al. (2003, p. 107) applies to Oryctocarella duyunensis.

We conclude that the designation of the crandium (E.M. 90001b) from Bergeron's (1899) limestone slab by Lane et al. (1988) is invalid. As discussed above, Bergeron's original illustration (1899, fig. 9) allows us to infer that E.M. 90001a was the intended 'type,' deemed a lectotype, of A. chauveaui despite the fact that Bergeron (1899) obviously regarded all specimens on the slab as belonging to the same species. According to Article 74.1.3 of the Zoological Code (ICZN, 1999), "The valid designation of a lectotype permanently deprives all other specimens that were formerly syntypes of that nominal taxon of the status of syntype." Because the intended 'type' can be unequivocally identified from the syntypic series through comparison to the original illustration (Bergeron, 1899, fig. 9), subsequent designation of any other specimen as a lectotype would be invalid and misleading. Furthermore, in accordance with Recommendation 74B of the Code (ICZN, 1999), "Other things being equal, an author who designates a lectotype should give preference to a syntype of which an illustration has been published." Bergeron's illustration (1899, fig. 9) was evidently based on a single specimen, E.M. 90001a, and this specimen therefore should have priority for designation as a lectotype over any non-illustrated sclerite in the original syntypic series.

\section{Historical review of Arthricocephalus and its junior synonyms}

Saito (1934, p. 232, pl. 25, figs. 26-29) questionably referred some specimens from northwestern Korea to Arthricocephalus. According to Rasetti (1959, p. O220) and Blaker and Peel (1997, p. 109), these specimens do not belong to Arthricocephalus but to Cheiruroides Kobayashi, 1935. Rasetti (1959, p. O524) regarded the genus Arthricocephalus to be unrecognizable and therefore failed to include it in the family Oryctocephalidae.

Qian (1961) assigned some specimens from the Balang Formation at Palang, Duyun, southeastern Guizhou, China, to a new species of Arthricocephalus, A. duyunensis. Qian's (1961) material is from a locality $\sim 100 \mathrm{~km}$ southwest of Tongren, the type locality of $A$. chauveaui. As revised here, these specimens 
are all referable to Oryctocarella, showing that Qian's (1961) paper influenced subsequent work on Arthricocephalus and created confusion about the concepts of both Oryctocarella and Arthricocephalus (see Qian and Lin in Zhou et al., 1977; Yin and Li, 1978; Zhang et al., 1980; Liu, 1982; Ju, 1983; Zhang and Zhou, 1985; Blaker, 1986; Blaker and Peel, 1997; Yuan et al., 2002, 2006; McNamara et al., 2003; Geyer, 2005; Peng et al., $2005 \mathrm{a}, \mathrm{b})$. Subsequent synonymization of Oryctocarella with Arthricocephalus (Suvorova, 1964; Shergold, 1969; Blaker and Peel, 1997) apparently stems in part from this broad interpretation of Arthricocephalus.

Tomashpolskaya (in Khalfin, 1960, p. 199, pl. 23, fig. 5) erected a new species, Oryctocara sibirica, and this species was later used (Tomashpolskaya and Karpinski, 1961) as the type species of the new genus Oryctocarella. Suvorova (1964, p. 235) considered the genus to be a junior synonym of Arthricocephalus. This suppression proved to be incorrect and, as revised here, Oryctocarella is revived as an independent genus.

Qian and Lin (in Lu et al., 1974) erected a monotypic subgenus Arthricocephalus (Arthricocephalites) with the new species A. (Arthricocephalites) xinzhaiheensis as its type species. Differential characteristics of the subgenus were not published until six years later. At that time Qian and Lin (in Zhang et al., 1980, p. 275-279) stated that A. (Arthricocephalites) differed from A. (Arthricocephalus) in having a longer palpebral lobe, a narrower fixigena, and a shorter (exsag.) posterior area of the fixigena. As now understood, their concept of A. (Arthricocephalus) is identical with that of Oryctocarella, whereas their concept of A. (Arthricocephalites) is identical with that of Arthricocephalus (as revised here).

The unfortunate designation of cranidium E.M. $90001 \mathrm{~b}$ as the lectotype of Arthricocephalus chauveaui Bergeron, 1899 by Lane et al. (1988) has led to misunderstanding about the concept of Arthricocephalus. The cranidium is here referred to Oryctocarella duyunensis (Qian, 1961). Some generic names have been mistakenly interpreted as junior synonyms of Arthricocephalus (see Blaker and Peel, 1997; Yuan et al., 2002), and some species have been mistakenly interpreted as Arthricocephalus (see Blaker and Peel, 1997; Yuan et al., 2002; McNamara et al., 2003; Yuan et al., 2006; Geyer and Peel, 2011).

Blaker and Peel (1997, p. 109) were unable to determine any consistent differences between A. (Arthricocephalus) and A. (Arthricocephalites), citing individual variability in the three features identified by Qian and Lin (in Zhang et al., 1980) as differentiating the subgenera. For this reason, Blaker and Peel (1997) suppressed A. (Arthricocephalites) as a junior synonym of Arthricocephalus. However, they included specimens now referable to Arthricocephalus (Blaker and Peel, 1997, fig. 62.1) and Oryctocarella (Blaker and Peel, 1997, fig. 62.2, 62.3) in A. chauveaui, leading to a broad concept of Arthricocephalus that embraces what we now consider to be Arthricocephalus and Oryctocarella.

In their 1997 paper, Blaker and Peel also erected a new genus, Haliplanktos, with Arthricocephalus (Arthricocephalites) jishouensis Zhou in Zhou et al., 1977 as its type species (Blaker and Peel, 1997, p. 112). Haliplanktos, as revised here, is regarded as a junior synonym of Arthricocephalus, and A. (A.) jishouensis is apparently based on a meraspid of A. chauveaui (Lei, 2016, and discussion below).
Yuan et al. (2002, p. 120-123) elevated A. (Arthricocephalites) and $A$. (Arthricocephalus) to generic rank and did not fully accept Blaker and Peel's (1997) synonymization of the taxa. They argued that Arthricocephalus differs from Arthricocephalites in having a proportionately wide cranidium with a broad fixigenae; narrow librigenae; a cylindrical glabella; short palpebral lobes; proparian facial sutures; a thorax having a narrow axis and eight to $11 \mathrm{seg}$ ments; a small (micropygous [or heteropygous; see Kobayashi, 1942]) pygidium with four to five axial rings and well-defined interpleural furrows. In contrast, Arthricocephalites, in their view, is characterized by having a narrower crandium with narrow fixigenae; wide librigenae; a forwardly expanding glabella; moderately long palpebral lobes; a gonatoparian facial suture; a thorax with a relatively wide axis and five to eight segments; a large (isopygous) pygidium with six to eight axial rings and faint or obsolescent interpleural furrows. The concept of Arthricocephalus used by Yuan et al. (2002) equates to that of Oryctocarella as revised here, whereas their concept of Arthricocephalites equates to that of Arthricocephalus as revised here.

McNamara et al. (2003) considered A. (Arthricocephalites) ( = Arthricocephalites of Yuan et al., 2002) and Arthricocephalus (sensu Yuan et al., 2002) to be synonymous. Their concept of Arthricocephalus embraced taxa assigned here to both Arthricocephalus and Oryctocarella.

The concept of Arthricocephalus used by Geyer and Peel (2011), being guided by the publication of Lane et al. (1988), equates to that of Oryctocarella as used here. Geyer and Peel (2011) considered Haliplanktos to be a valid genus, whereas as revised here, it is considered to be a junior synonym of Arthricocephalus.

Large collections of oryctocephalid trilobites, including some topotypic material, have been amassed from the Balang Formation in eastern Guizhou and western Hunan onward from about 1961 (see Qian, 1961; Zhou in Zhou et al., 1977; Yin and Li, 1978; Zhang et al., 1980; Yuan et al., 2002, 2006, 2009; McNamara et al., 2003, 2006; Peng et al., 2006; Ma et al., 2011; Lei and Peng, 2014; Lei, 2016), and this material helps to clarify the morphology and characterize the various taxa now under discussion. Together with restudy of Bergeron's (1899) slab from the Balang Formation of eastern Guizhou, the new material provides clarification about the concept of Arthricocephalus, and leads us to revive Oryctocarella as an independent, well-recognizable genus, and to regard Arthricocephalites and Haliplanktos as junior synonyms of Arthricocephalus.

\section{Validity of Oryctocarella}

Tomashpolskaya and Karpinski (1961) erected the genus Oryctocarella (with Oryctocara sibirica Tomashpolskaya in Khalfin, 1960 as the type species) for an oryctocephalid trilobite based on material from the Kuznetsk Alatau of the Altay-Sayan Foldbelt, southwestern Siberia. At that time, at least 10 variously complete exoskeletons were known. Oryctocarella was characterized by having eight thoracic segments (similar to the number of segments in Arthricocephalus chauveaui). The Siberian material appears to be congeneric with material from eastern Guizhou that was incorrectly assigned to Arthricocephalus by Qian (1961), leading Suvorova (1964, p. 235) to suppress 
the monospecific Oryctocarella as a junior synonym of Arthricocephalus. Blaker and Peel (1997, p. 109) likewise suppressed Oryctocarella, noting that the holotype exoskeleton of $O$. sibirica is "comparable in all morphological features to A. chauveaui." Shergold (1969, p. 40) noted that $O$. sibirica has segmentation identical with Arthricocephalus chauveaui, and that Suvorova (1964) had considered the two genera as possible synonyms. However, Peng et al. (2015) considered that Oryctocarella should be revived as a valid genus because it is significantly distinguishable in exoskeletal characters from Arthricocephalus.

Unfortunately, the type material of Tomashpolskaya and Karpinski (1961) is lost (Korovnikov and Novozhilova, 2017), and the original figures of $O$. sibirica are poor, making it hard to determine its diagnostic features, especially the exact number of thoracic segments. From the original illustration of the holotype (Tomashpolskaya and Karpinski, 1961, pl. 1, fig. 2), it appears that $O$. sibirica has at least nine thoracic segments. Recently collected topotypic material of $O$. sibirica from its type locality in the Kuznetsk Alatau, Altay-Sayan Foldbelt (see Fig. 6) reveals that the species has nine or possibly 10 thoracic segments. In addition, topotypes show that $O$. sibirica shares a number of important characters with $O$. duyunensis, allowing clear distinction from A. chauveaui (see Fig. 3). Distinguishing characters include a cylindrical glabella, pit-like glabellar furrows that are isolated from the axial furrows, a non-fulcrate thorax, and a relatively short pygidium with clearly defined interpleural furrows. A pygidial border and border furrow are not defined. These characters clearly differentiate Oryctocarella from Arthricocephalus so that, following Peng et al. (2015) and Korovnikov and Novozhilova (2017), the genus must be regarded as valid and discrete.

A large number of specimens from China previously assigned to Arthricocephalus are referable to Oryctocarella. They include specimens illustrated as Arthricocephalus duyunensis Qian, 1961, A. granulus Qian and Lin in Zhou et al., 1977, A. jiangkouensis Yin in Yin and Li, 1978, A. tenuis Zhang and Zhou, 1985, and A. cf. A. granulus sensu Zhang and Zhou, 1985. Some of these described species are regarded here as synonymous with Oryctocarella duyunensis (Qian, 1961).

\section{Materials and methods}

Figured specimens were collected from the Cambrian Balang Formation in various localities of South China and from the lower part of the traditional Middle Cambrian in a single locality of Siberia, Russia. The localities are indicated by these acronyms: $\mathrm{BL}=$ Bulin, Huayuan, northwestern Hunan, China; DZ = Nangao, Danzhai, eastern Guizhou, China; DM = Dolgii Mys (Long Cape) Mountain, Khakassia, Batenevsky Ridge, Kuznetsk Alatau, Altay-Sayan Foldbelt, Russia; GY = Palang (previously misspelled as Balang), Duyun, southeastern Guizhou, China; HN-GZ = Border area between Hunan and Guizhou provinces, China (exact collecting locality unknown); $\mathrm{KH}=$ Panxin and Feilongshan, Songtao, eastern Guizhou, China; LYX = Luoyixi, Guzhuang, northwestern Hunan, China; MZC = Mozichong, Huayuan, northwestern Hunan, China; TJBL = Balang, Taijiang, eastern Guizhou, China; $\mathrm{TR}=$ Tongren, eastern Guizhou, China; $\mathrm{WW}=\mathrm{Wawu}$, Tongren, Guizhou, China (village that has administrative jurisdiction over the type locality of $A$. chauveaui); XHZA = Paiwu (Zila A), Huayuan, northwestern Hunan, China; XHZB = Paiwu (Zila B), Huayuan, northwestern Hunan, China; XS = Xiaosai, Yuqing, eastern Guizhou, China.

Specimens in Bergeron's (1899) type series of Arthricocephalus chauveaui were coated with magnesium oxide and then photographed with an Olympus OM4 film camera. Topotypes of Oryctocarella sibirica were photographed with a digital camera. All other specimens were coated with black ink and followed by magnesium oxide, then photographed under a Zeiss stereomicroscope (Model Axio Zoom V16) having a digital head (AxioCam MrM) and a circle light around the lens providing uniform lighting. Measurements were made from images of sclerites using the ruler tool in Adobe Photoshop CS6. Scale bars were either photographed along with the images of specimens by film photography or produced automatically by digital photography.

Repositories and institutional abbreviations.-_Illustrated and referred specimens are deposited in the following institutions: CSGM, Central Siberian Geological Museum, Novosibirsk, Russia; E.M., Geological Department, Claude Bernard University, Lyon, France; Gt, Guizhou Institute of Regional Geological Survey, Guiyang, Guizhou, China; NIGP, Nanjing Institute of Geology and Palaeontology, Nanjing, China; NWU, Geological Department, Northwest University, Xi'an, China.

Spellings of author names.-English spellings of the names of some Chinese authors have changed through time. The Pinyin (Chinese Phonetic Alphabet), introduced in 1958, was accepted in 1982 as the International Standard for the Spelling of Chinese Characters (ISO7098), and it is Pinyin spellings that are used here. Names of Chinese authors affected by the change to Pinyin spellings include Guo (changed from Kuo), Li (from Lee), Qian (from Chien), Xiang (from Hsiang), Zhang (from Chang), and Zhu (from Chu).

Transliterated names of Russian authors follow commonly accepted spellings.

\section{Systematic paleontology}

Terminology mostly follows that of Whittington and Kelly (1997). In the following descriptions, "long" and "short" are used with reference to longitudinal (sagittal, sag., and exsagittal, exsag.) dimensions, and "broad" (or "wide") and "narrow" are used with reference to transverse (tr.) dimensions (Whittington, 1997, p. O2).

Order Corynexochida Kobayashi, 1935

Family Oryctocephalidae Beecher, 1897

Subfamily Oryctocarinae Hupé, 1953

Genus Arthricocephalus Bergeron, 1899

1899 Arthricocephalus Bergeron, p. 514.

1974 Arthricocephalus (Arthricocephalites) Qian and Lin in Lu et al., p. 94.

1988 Arthricocephalus Bergeron; Lane et al. (part), p. 555.

1997 Haliplanktos Blaker and Peel, p. 112.

2002 Arthricocephalites Qian and Lin in Yuan et al., p. 122. 
Type species.-Arthricocephalus chauveaui Bergeron, 1899, p. 514, text-fig. 9, from the Balang Formation, near Tongren, eastern Guizhou, China; by monotypy.

Other species.-Arthricocephalus (Arthricocephalites) xinzhaiheneis Qian and Lin in Lu et al., 1974, p. 95, pl. 36, fig. 7, from the Balang Formation, at Panxin, Songtao, eastern Guizhou, China.

Diagnosis.-Isopygous or subisopygous genus of Oryctocarinae with arched cranidial anterior margin; glabella parallelsided along L1-L2 or L1-L3, expanded forward anterior to S2 or S3, defined laterally by outwardly curved axial furrow; S1-S3 pit-like or narrow furrows, connected by transglabellar furrows terminating at the pits or continuing laterally to the axial furrows; palpebral lobe moderately long, slightly oblique; palpebral area slightly narrower than glabella; facial suture gonatoparian; librigena narrow. Thorax fulcrate, with eight segments; axis moderately wide. Pygidium nearly as long as cranidium, axis with five rings plus a terminal piece; pleural furrows wide and clearly defined, interpleural furrow faint; pygidial border upturned and poorly defined by wide border furrow; posterior margin without medial notch.

Remarks.-As summarized above, identification of E.M. 90001a as Bergeron's (1899) intended 'type' (now lectotype) of Arthricocephalus chauveaui leads to revision of the generic concepts of Arthricocephalus and Oryctocarella. New synonymies are introduced, and Haliplanktos is considered to be a junior synonym of Arthricocephalus.

Arthricocephalus resembles Oryctocarella, which is revived here as a separate genus. Characters that distinguish Arthricocephalus from Oryctocarella include a forwardly expanding glabella, curved axial furrows, glabellar furrows reaching the axial furrows, a fulcrate thorax with eight segments, and a relatively large pygidium with poorly defined interpleural furrows and a well-defined border. Oryctocarella, in contrast, has a cylindrical glabella, straight axial furrows, pitted S1-S3 glabellar furrows that are isolated from axial furrows, a non-fulcrate thorax with nine or 10 segments, and a relatively short pygidium with well-defined interpleural furrows and a poorly defined pygidial border.

New material from northwestern Hunan shows that the holotype of A. (Arthricocephalites) jishouensis, the type species of Haliplanktos, is a meraspid degree 6 of Arthricocephalus chauveaui (Lei, 2016). New material also shows that A. (Arthricocephalites) xinzhaiheensis, the type species of A. (Arthricocephalites), shares general diagnostic characters with A. chauveaui, differing only in the nature of the S1-S3 glabellar furrows, which are pitted and connected with transverse furrows between pits. Both species are reassigned here to Arthricocephalus.

Representatives of Arthricocephalus are known from South China (Guizhou and Hunan provinces) and North Greenland, and range in position from Cambrian Stage 4 (Duyunian of the South China regional standard) to Stage 5 (Taijiangian of South China).
Arthricocephalus chauveaui Bergeron, 1899

Figures 1.1, 1.2, 2.1-2.3, 2.10, 2.11, 3.1, 4

1899 Arthricocephalus chauveaui Bergeron, p. 514, fig. 9.

1957 Arthricocephalus chauveaui; Lu, p. 265, pl. 139, fig. 11.

1962 Arthricocephalus chauveaui; Lu et al., p. 27, pl. 1, fig. 9, pl. 6, fig. 10.

1963 Arthricocephalus chauveaui; Lu et al., p. 64, pl. 7, figs. 7a-d.

1963 Arthricocephalus chauveaui; Egorova et al., p. 20, pl. 2, fig. 9.

non 1964 Arthricocephalus chauveaui; Lu and Qian, p. 26, pl. 1, fig. 5.

1965 Arthricocephalus chauveaui; Lu et al., p. 108, pl. 17, fig. 1.

1977 Arthricocephalus (Arthricocephalites) jishouensis Zhou in Zhou et al., p. 131, pl. 42, figs. 4-6.

non 1977 Arthricocephalus chauveaui; Zhou et al., p. 130, pl. 42 , fig. 3 .

1978 Arthricocephalus (Arthricocephalites) tongrenensis Yin in Yin and Li, p. 442, pl. 155, fig. 17.

1978 Arthricocephalus taijiangensis Yin in Yin and Li, p. 441 , pl. 156, fig. 8 .

non 1980 Arthricocephalus chauveaui; Zhang et al., p. 275, pl. 92, figs. 1, 2.

1980 Arthricocephalus (Arthricocephalites) pulchellus Zhang and Qian in Zhang et al., p. 276, pl. 92, fig. 3.

1982 Arthricocephalus chauveaui; Liu, p. 300, pl. 213, fig. 9.

1982 Arthricocephalus (Arthricocephalites) jishouensis; Liu, p. 300, pl. 213, figs. 7, 8, 11.

1988 Arthricocephalus chauveaui; Lane et al. (part), p. 555, pl. 1, figs. 1, 5; non figs. 2-4, 6 .

1997 Arthricocephalus chauveaui; Blaker and Peel (part), p. 109, fig. 62.1; non figs. 62.2, 62.3, 63, 64.1-64.4.

1997 Haliplanktos jishouensis (Zhou); Blaker and Peel, p. 112, fig. 64.5-64.7.

2001 Arthricocephalites taijiangensis; Yuan et al., pl. 2, fig. 5 .

2002 Arthricocephalites taijiangensis; Yuan et al., p. 123, pl. 30, figs. 3-5, pl. 31, figs. 2-6.

non 2002 Arthricocephalus chauveaui; Yuan et al., p. 121, pl. 31, fig. 1.

non 2003 Arthricocephalus chauveaui; McNamara et al., p. 106, pl. 1, figs. 1-15, pl. 2, figs. 5, 7, text-fig. 3A-K.

2003 Arthricocephalus pulchellus; McNamara et al., p. 115 , pl. 2, figs. $10-12$, text-fig. $6 \mathrm{~A}, 6 \mathrm{~B}$.

2005 Arthricocephalus chauveaui; Geyer (part), p. 87, fig. 3.7; non fig. 3.1-3.4, 3.8, 3.9.

2005 Haliplanktos jishouensis; Geyer, p. 88, fig. 3.5, 3.6. non 2005a Arthricocephalus chauveaui; Peng et al., p. 1161, fig. 2e.

non 2005b Arthricocephalus chauveaui; Peng et al., p. 1056, fig. 2e.

2006 Arthricocephalus xinzhaiheensis Qian and Lin; Yuan et al. (part), p. 617, fig. 2b; non fig. 2a.

non 2006 Arthricocephalus chauveaui; Yuan et al., p. 615, fig. 1d, 1e. 
2006 Arthricocephalites taijiangensis; Yuan et al., 2009 p. 617 , fig. 2c-j.

non 2006 Arthricocephalus chauveaui; Peng et al., p. 241, 2011 pl. 1, fig. 11.
Arthricocephalus chauveaui; Yuan et al., p. 214, fig. 1c, 1cc'.

Arthricocephalites taijiangensis; Ma et al., p. 746, fig. 3c.
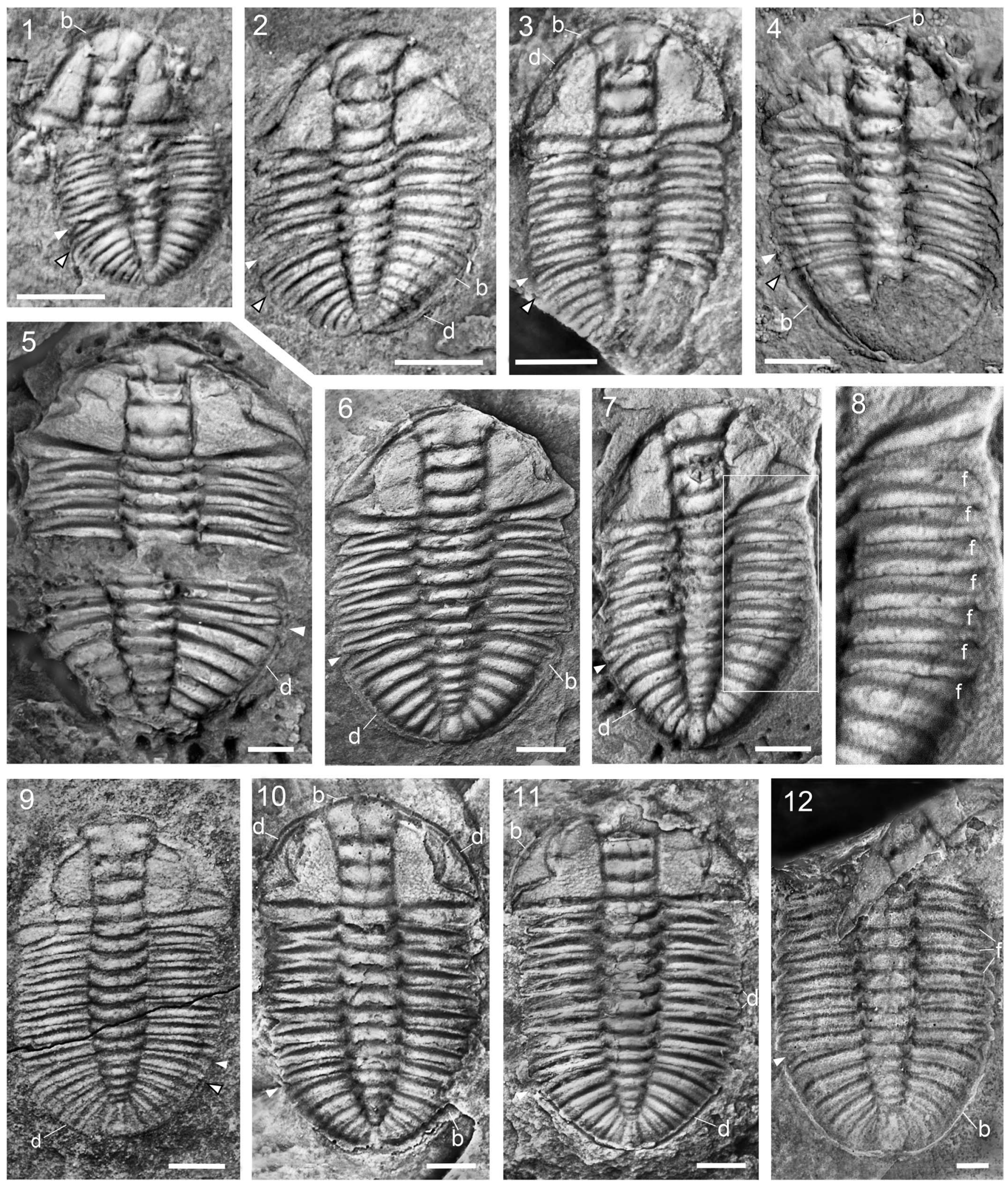
2011 Haliplanktos jishouensis; Geyer and Peel, p. 499, fig. $15 \mathrm{~A}-\mathrm{F}$.

2013 Arthricocephalus xinzhaiheensis; Lei, p. 72, figs. 24, 25.

2015 Arthricocephalus chauveaui; Peng et al., p. 89, pl. 1, figs. 1-4.

2016 Arthricocephalus chauveaui; Lei (part), p. 496, figs. 3.1-3.4, 3.6, ?3.8, 3.9-3.12, 3.14, ?3.15, 4.1-4.3, 4.5, 4.6, 4.8, ?4.9-4.16; non figs. 3.5, 3.7, 3.13, 4.2, 4.7.

2016 Arthricocephalites xinzhaiheensis; Shen et al. (part), p. 16, fig. 1.8-1.11; non fig. 1.1-1.7.

2016 Arthricocephalites intermedius Zhou; Shen et al., p. 15, fig. 2.1-2.3, 2.6-2.13, ?2.4, ?2.5.

Lectotype.-Disarticulated exoskeleton (E.M. 90001a; Figs. $1.1,2.2,2.3,2.10$ ); also illustrated by Lane et al. (1988, pl. 1, fig. 1), Blaker and Peel (1997, fig. 62.1), and Geyer (2005, fig. 3.7), from the Balang Formation, north of Tongren, eastern Guizhou, China; original of Bergeron (1899, fig. 9).

Diagnosis.-Arthricocephalus with glabellar furrows continuous transversely across glabella, reaching to axial furrow; glabella expanded forward of S2 or S3; preocular area nearly half as long (exsag.) as frontal lobe (sag.); palpebral lobe slightly oblique to almost exsagittal in holaspid stage with posterior end at a level corresponding to S1; posterior branch of facial suture strongly divergent, curving posterolaterally to meet cephalic margin at genal corner or faintly anterior to it. Dorsal surface smooth or covered with fine granules.

Occurrence.-Arthricocephalus chauveaui has been reported from the Jiangnan Slope Belt of eastern Guizhou and western Hunan, South China, and (as Haliplanktos jishouensis) from North Greenland. In Guizhou and Hunan, it occurs in dark-gray, calcareous mudstone and shale (weathering yellow-green) in the middle part of the Balang Formation (Cambrian Stage 4 or Duyunian according to South China regional stratigraphy). In Greenland, it occurs in the Olenellus Zone of the Henson Gletscher Formation (Cambrian Stage 4).

Description.—Exoskeleton ovate, length $\sim 1.5$ times width. Cephalon semicircular; glabella forwardly expanding or pestleshaped, expanded anterior to S2 or S3, with transverse occipital furrow. Four pairs of glabellar furrows present; S1-S3 transverse across glabella, extending to axial furrows and deepened laterally into paired pits near axial furrows, S4 narrow incision, reaching to axial furrow abaxially. Occipital ring wider and slightly shorter than L1, S0 and S1-S4 subequally spaced, frontal lobe slightly longer than L4. Palpebral lobe mediumsized, of $\sim 0.33-0.36(\mathrm{~N}=6)$ of cephalic length in adult specimens, gently curved, moderately to gently oblique and directed moderately forward, with posterior tip in adult specimens opposite S1; palpebral area about three-quarters width of glabella at L2. Anterior branch of facial suture short and straight, diagonally convergent forward; posterior branch strongly divergent for about two-thirds its length, then curving smoothly to meet cephalic margin at genal corner or faintly anterior to it. Librigena narrow, lateral border narrow and upturned, with well-defined border furrow. Anterior cranidial border ridge-like and narrow, upturned, with well-defined border furrow; posterior border slightly shorter than occipital ring, becoming much longer abaxially, with well-developed and moderately long (exsag.) posterior furrow.

Rostral-hypostomal plate (Fig. 2.10) shield-shaped; middle body of hypostoma large, elliptical, gently convex, divided by a faint medial furrow, posterior portion short crescentic; anterior wing triangular, about half as long as hypostome, lateral and posterior borders narrow (tr., sag.), with deep border furrows. Rostral plate narrow, ridge-like, separated from ridge-like cephalic doublure by short connective suture.

Thorax fulcrate, with eight segments. Axis gently narrowing posteriorly, slightly expanded medially, pleural region $\sim 1.5$ as broad as axis, fulcrum present about halfway across width (tr.) of pleura; anterior and posterior bands of pleura subequally long (exsag.), separated by deep and long pleural furrow; anterior margin of pleura curves backward to a sharply pointed or acute posterolateral tip.

Pygidium semicircular, as long as cephalon or slightly shorter, length/width ratio $\sim 0.48-0.53(\mathrm{~N}=8)$. Axis consists of five rings and a tiny terminal piece, tapering rapidly rearward, of about two-thirds of pygidial length. Pleural region moderately convex, with five or six pleurae consisting of subequal anterior and posterior bands; pleural furrow nearly straight, well impressed and broad (exsag.); interpleural furrows less well developed, sometimes faint. Lateral and posterior borders upturned; border furrows broad, shallow, of unequal depth due to faintly elevated parts in continuation of the pleural bands. Pygidial doublure narrow, belt-like.

Dorsal surface smooth or covered with fine but densely spaced granules.

Materials.-Eight exoskeletons including five in collection LYX-1 (NIGP 164838-164841, 164952), one in collection WWf2 (NIGP 164842), and two in collection XHZA329-13 and XHZA325-27, respectively (NIGP 163349, 163354).

Figure 4. Arthricocephalus chauveaui Bergeron, 1899 from the Balang Formation in northwestern Hunan (1-5, 7, 8, 10-12) and eastern Guizhou (6, 9), China. White arrowhead indicates posterior margin of thorax; arrowhead with black outline indicates posterior margin of partially released segment of transitory pygidium; all in dorsal view; $\mathrm{b}=$ border, $\mathrm{d}=$ doublure; $\mathrm{f}=$ facet: (1) NIGP 164838, exoskeleton, meraspis degree 4, LYX-1; (2) NIGP 164839, exoskeleton, meraspis degree 4, LYX-1; (3) NIGP 163346, exoskeleton, meraspis degree 5, XHZA407-3, original of Lei (2015, fig. 3.3); (4) NIGP 164952, distorted exoskeleton, meraspis degree 5, LYX-1; (5) NIGP 164840, exoskeleton, meraspis degree 6, LYX-1; (6) NIGP 38233, exoskeleton, meraspis degree 6, HN-GZ, holotype of Arthricocephalus (Arthricocephalites) pulchellus Zhang and Qian in Zhang et al. (1980, pl. 92, fig. 3); illustrated originally as Arthricocephalus chauveaui by Lu et al. (1965, pl. 17, fig. 1), reillustrated as Arthricocephalus taijiangensis by Yuan et al. (2001, pl. 2, fig. 5; 2006, fig. 2c) and as Arthricocephalus pulchellus by McNamara et al. (2003, pl. 2, fig. 12); (7) NIGP 164841, exoskeleton, meraspis degree 6, LYX-1; (8) enlargement of the right side of the thorax of NIGP 164841 in 7, showing pleural facets; (9) NIGP 164842, exoskeleton, meraspis degree 7, WWf2; (10) NIGP 163349, exoskeleton, holaspid, latex cast from external mold, XHZA329-13; (11), NIGP 163354, exoskeleton, holaspid, XHZA325-27; (12) NIGP 163357, latex cast of external mold of incomplete holaspid exoskeleton lacking librigenae and with displaced cranidium, XHZA416-9, original of Lei (2016, fig. 3.14). All scale bars represent $1.0 \mathrm{~mm}$. 
Reillustrated specimens include the holotype exoskeleton of Arthricocephalus (Arthricocephalites) pulchellus Zhang and Qian in Zhang et al., 1980 (NIGP 38233) and two exoskeletons assigned by Lei (2016) to Arthricocephalus chauveaui Bergeron (NIGP 163346, 163357).

Remarks.-A new diagnosis and description of Arthricocephalus chauveaui are presented here because the concept of the species and the genus are significantly revised. Most species that were previously referred to A. (Arthricocephalites), Arthricocephalites, and Haliplanktos are now synonymized with $A$. chauveaui either because they closely resemble the lectotype exoskeleton of A. chauveaui (E.M. 90001a), or because they closely resemble meraspides of the species.

Material from the Balang Formation of northwestern Hunan and eastern Guizhou shows that the holaspid exoskeleton of Arthricocephalus chauveaui has eight thoracic segments. This suggests that some species referred to Arthricocephalus, A. (Arthricocephalites), and Haliplanktos and the assigned species with fewer than eight thoracic segments are all based on meraspides. Those species are: Arthricocephalus taijiangensis, A. pulchellus, A. (Arthricocephalites) jishouensis (also published as Haliplanktos jishouensis), and A. (Arthricocephalites) tongrenensis. Arthricocephalus taijiangensis (Yin and Li, 1978, pl. 156, fig. 8) is based on an individual having five thoracic segments. Arthricocephalus (Arthricocephalites) tongrenensis (Yin and $\mathrm{Li}, 1978$, pl. 157, fig. 17) is based on an individual having seven thoracic segments. Holotypes of A. (Arthricocephalites) jishouensis (Zhou et al., 1977, pl. 42, fig. 4) and A. (Arthricocephalites) pulchellus (Zhang et al., 1980, pl. 92, fig. 3) are individuals having six thoracic segments.

Blaker and Peel (1997, p. 109) referred the type material of Ovatoryctocara granulata (Chernysheva 1962, pl. 5, figs. 6-8) to Arthricocephalus chanveaui. As discussed above, their concept of A. chauveaui embraced both A. chauveaui and Oryctocarella duyunensis. Based on a rather large number of specimens now known from Russia, Greenland, and Newfoundland (e.g., Fletcher, 2003; Korovnikov and Shabanov, 2008; Naimark et al., 2011; Geyer and Peel, 2011), it is evident that Ovatoryctocara granulata is distinct from both $A$. chauveaui and $O$. duyunensis. It differs in having a prominent preocular field that is relatively long (as compared to the short preocular field in A. chauveaui and O. duyunensis), in having a glabella that is commonly defined by sinuous axial furrows, a pair of longitudinal furrows connecting S1-S3, pit-like glabellar furrows exsagittally, and a palpebral lobe that is moderately close to the glabella. The thorax of $O$. granulata has only four segments in the holaspid stage, and the pygidium is proportionally longer than that of either A. chauveaui or $O$. duyunensis; it has more axial rings and lacks a border.

In their synonymy of A. chauveaui, Blaker and Peel (1997, p. 110) referred some additional Russian specimens to $A$. chauveaui. They include a pygidium assigned to Neopagetina nomokonovi by Semashko (1969, pl. 1, fig.13) and a cranidium and a pygidium referred to Oryctocara (Ovatoryctocara) sp. by Chernysheva (1971, pl. 13, figs. 8, 9). However, the illustrations of these specimens show that they do not belong to either Arthricocephalus, as revised here, or to Oryctocarella. They are more likely specimens of the genus Ovatoryctocara.

As revised, some whole or partial specimens that were previously assigned to A. chauveaui are now referred to Oryctocarella duyunensis Qian, 1961 (e.g., Qian, 1961; Lu and Qian, 1964; Zhou et al., 1977; Zhang et al., 1980; Lane et al., 1988; Blaker and Peel, 1997; Yuan et al., 2002, 2006; McNamara et al., 2003; Geyer, 2005; Peng et al., 2005a, 2005b; 2006).

Arthricocephalus xinzhaiheensis Qian and Lin in Lu et al., 1974 Figure 5

1974 Arthricocephalus (Arthricocephalites) xinzhaiheensis Qian and Lin in Lu et al., p. 95, pl. 36, fig. 7.

1974 Arthricocephalus (Arthricocephalites) intermedius Zhou in Lu et al., p. 95, pl. 36, fig. 8.

1978 Arthricocephalus (Arthricocephalites) intermedius; Yin and Li, p. 441, pl. 156, fig. 10.

1978 Arthricocephalus (Arthricocephalites) xinzhaiheensis; Yin and Li, p. 441, pl. 157, fig. 1.

1980 Arthricocephalus (Arthricocephalites) xinzhaiheensis; Zhang et al. (part), p. 276, pl. 92, figs. 5, 6; non pl. 93, fig. 1.

1980 Arthricocephalus (Arthricocephalites) intermedius; Zhang et al., p. 278, pl. 92, fig. 4.

?1980 Arthricocephalites (Arthricocephalites) sp. 2, Zhang et al., p. 279, pl. 93, fig. 8 .

2002 Arthricocephalites xinzhaiheensis; Yuan et al., p. 123, pl. 30, figs. 6, 7.

non 2003 Arthricocephalus xinzhaiheensis; McNamara et al., p. 111, pl. 2, figs. 1-4, text-fig. 4A-D.

2006 Arthricocephalites xinzhaiheensis; Yuan et al. (part), p. 617, fig 2a; non fig. 2b.

2016 Arthricocephalites xinzhaiheensis; Shen et al., (part), fig. 1.1-1.7; non fig. 1.8-1.11.

2016 Arthricocephalus chauveaui Bergeron; Lei (part), p. 496, figs. 3.5, 3.7, 3.13, 4.2, 4.7; non figs. 3.1-3.4, $3.6, ? 3.8,3.9-3.12,3.14, ? 3.15,4.1-4.3,4.5,4.6$, $4.8, ? 4.9-4.16$.

Figure 5. Arthricocephalus xinzhaiheensis Qian and Lin in Lu et al., 1974 from the Balang Formation in eastern (1, 2, 6-8) and southeastern (3) Guizhou and northeastern Hunan $(\mathbf{4}, \mathbf{5}, \mathbf{9 - 1 3})$, China; all in dorsal view. White arrowhead indicates the posterior margin of thorax; arrowhead with black outline indicates the posterior margin of partially released segment of transitory pygidium; $b=$ border, $d=$ doublure, $\mathrm{f}=$ facet: (1) holotype, NIGP 38234, exoskeleton, KH071, original of Lu et al. (1974, pl. 36, fig. 7); (2) NIGP 38235, exoskeleton, KH070, original of Arthricocephalus (Arthricocephalites) xinzhaiheensis Qian and Lin (Zhang et al., 1980, pl. 92, fig. 6); (3) NIGP 21481, exoskeleton, DZ-53-upper, original of Arthricocephalus (Arthricocephalites) intermedius Zhou (Lu et al., 1974, pl. 36, fig. 8); (4) NIGP 163350, exoskeleton, XHZA 416-14, original of Lei (2016, fig. 3.7); (5) NIGP 164843, exoskeleton, meraspis degree 6, LYX-1; (6) NIGP 135415, exoskeleton, meraspis degree 5, GY(GPN2), original of Arthricocephalus balangensis (McNamara et al., 2003, pl. 2, fig. 6); (7) NIGP 135416, exoskeleton, meraspis degree 6, GY(GPN2), original of Arthricocephalus balangensis (McNamara et al., 2003, pl. 2, fig. 8); (8) NIGP 135417, exoskeleton, meraspis degree 7, GY(GPN2), original of Arthricocephalus balangensis (McNamara et al., 2003, pl. 2, fig. 9); (9) NIGP 163356, incomplete exoskeleton, meraspis degree 7, XHZA 351-15, original of Lei (2016, fig. 4.13); (10-11) NIGP 163348, holaspid exoskeleton (10), and latex cast from its external mold (11), XHZA404-13, original of Lei (2016, fig. 3.5); (12) NIGP 163365, cephalon with displaced right librigena and lacking left librigena, XHZA416-5, original of Lei (2016, fig. 4.7); (13) NIGP 163362, cranidium, XHZA404-20, original of Lei (2016, fig. 4.4). All scale bars represent 1.0 mm. 

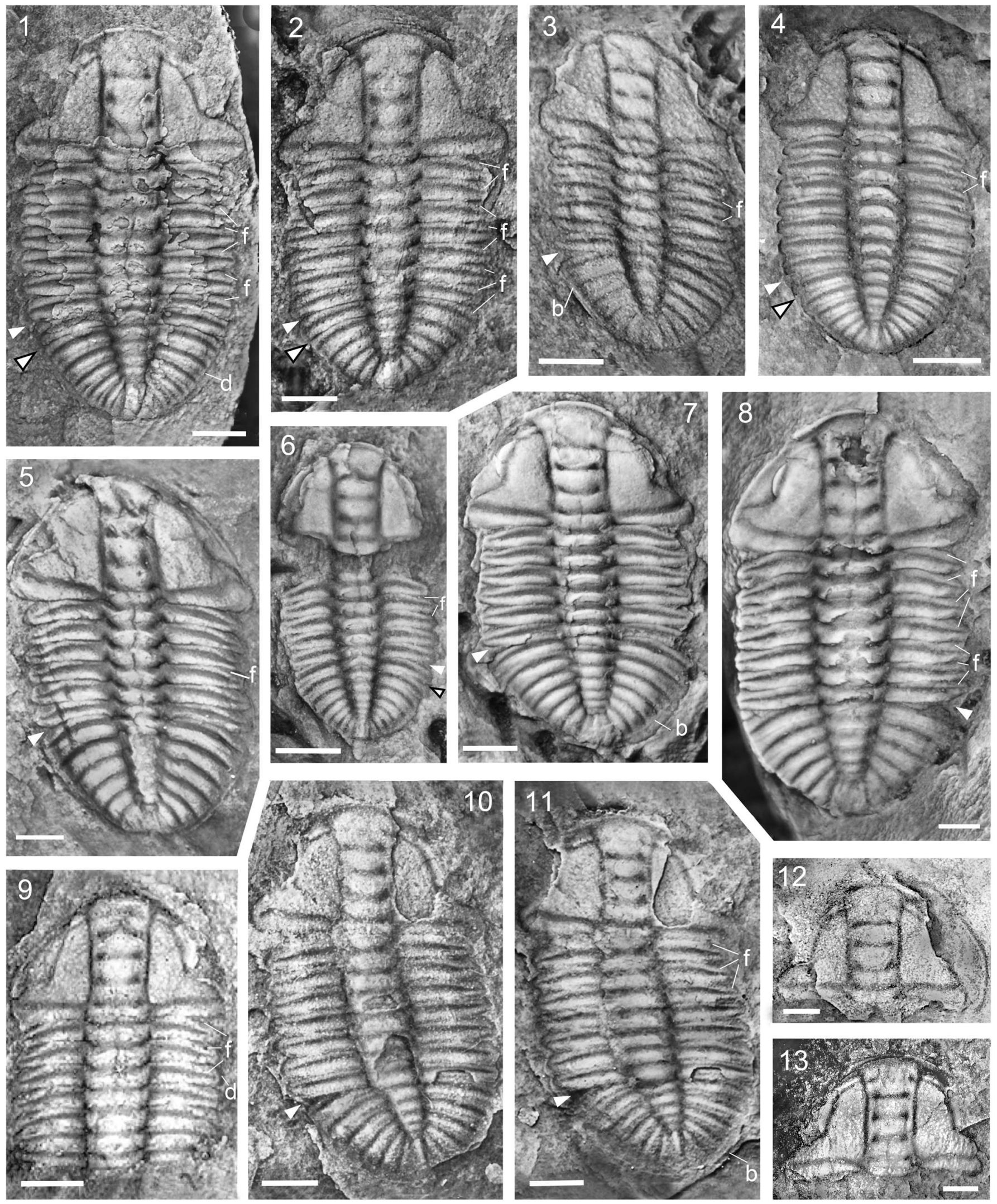
Holotype.-Exoskeleton (NIGP 38234, Fig. 5.1) from the Balang Formation, Xinzhaihe, Songtao, northeastern Guizhou, China; by monotypy. The holotype was figured by $\mathrm{Lu}$ et al. (1974, pl. 36, fig. 7), and refigured by Yin and Li (1978, pl. 157, fig. 1), Zhang et al. (1980, pl. 92, fig. 5), and Yuan et al. (2002, pl. 30, fig. 6). It is not the exoskeleton illustrated by Yuan et al. (2006, fig. 2a) as the holotype of the species.

Diagnosis.-Arthricocephalus with glabellar furrows S1-S3 pit-like, connected by weak transverse furrows, separated from axial furrow; palpebral lobe variably oblique in meraspis and holaspis with posterior end at a level corresponding to the posterior half or mid-length of L2; dorsal surface smooth or covered by densely spaced granules.

Occurrence.-Arthricocephalus xinzhaihenesis co-occurs with A. chauveaui in the Balang Formation of the Jiangnan Slope Belt, eastern Guizhou and western Hunan, South China. It is present in dark-gray, calcareous mudstone and shale (weathering yellow-green) in the middle part of the Balang Formation (Cambrian Stage 4 or Duyunian according to South China regional stratigraphy).

Materials.-One exoskeleton (NIGP 164843) in collections LYX-1. Reillustrated specimens include the holotype exoskeleton of Arthricocephalus (Arthricocephalites) xinzhaiheensis Qian and Lin in Lu et al., 1974 (NIGP 38234), the holotype exoskeleton of A. (Arthricocephalites) intermedius Zhou in Lu et al., 1974 (NIGP 21481), an exoskeleton assigned to $A$. (Arthricocephalites) xinzhaiheensis by Zhang et al., 1980 (NIGP 38235); three exoskeletons assigned to Arthricocephalus balangensis Lu and Qian in Yin and Li, 1978 (not Qian and Lin, as documented in Zhang et al., 1980) by McNamara et al., 2003 (NIGP 135415-135417); and four specimens assigned to Arthricocephalus chauveaui Bergeron by Lei (2016), including two exoskeletons (NIGP 163348, 163356), an incomplete cephalon (NIGP 163365), and an incomplete cranidium (NIGP 163362).

Remarks.-Lei (2016) suppressed Arthricocephalus xinzhaiheensis as a junior synonym of $A$. chauveaui. In most respects, such as shape of the glabella, morphology of the glabellar furrows, course of the facial suture, presence of thoracic fulcra, shape and subdivision of the pleurae, segmentation of the thorax and pygidium, faint interpleural furrows on the pygidium, and the upturned cephalic and pygidial borders, $A$. xinzhaiheensis closely resembles $A$. chauveaui. However, the species is distinct from $A$. chauveaui in having $\mathrm{S} 1-\mathrm{S} 3$ glabellar furrows that do not extend abaxially to the axial furrow, although they are joined by weak transverse furrows medially on the glabella. The palpebral lobe of A. xinzhaiheensis seems to be more oblique in adults, and the anterior tip of the palpebral lobe appears to be closer to the glabella than it is in A. chauveaui and the posterior tip places further back. In the holotype of $A$. xinzhaiheensis the axis of the thorax (Fig. 5.1) is proportionately broader than in A. chauveaui, but another specimen (Fig. 5.5) suggests variation in this character. In addition, the specimen in Figure 5.5 is indistiguishable from A. chauveaui in the proportion of the thoracic axis. In $A$. xinzhaiheensis the forward expansion of the glabella is variable.
Specimens assigned to Arthricocephalus balangensis by McNamara et al. (2003, pl. 2, figs. 6, 8, 9, text-fig. 5; Fig. 5.6, 5.7) differ significantly from the holotype of $A$. balangensis and are here transferred to $A$. xinzhaiheensis based on the morphology of the glabella and glabellar furrows, and on the presence of fulcra in the thorax. The holotype of $A$. balangensis (Yin and Li, 1978, pl. 157, fig. 10; refigured by Zhang et al., 1980, pl. 93, fig. 2; Fig. 7.1, 7.2) is similar to A. xinzhaiheensis in having pit-like $\mathrm{S} 1-\mathrm{S} 3$ joined by transverse furrows across the middle of the glabella. However, the glabella of $A$. balangensis is subrectangular or subcylindrical in shape, and defined by nearly straight, parallel axial furrows. Importantly, the thorax of A. balangensis lacks fulcra. The thorax normally has 11 segments, but in some examples one more segment may be developed. These characters support a reassignment of A. balangensis to Oryctocarella (and recombination as Oryctocarella balangensis, see below).

Specimens assigned to Arthricocephalus xinzhaihenesis by McNamara et al. (2003, pl. 2, figs. 1-4, text-fig. 4A-D) are reassigned here as Oryctocarella balangensis (see below), and specimens assigned to A. xinzhaihenesis by Yuan et al., 2006 (fig. 2b) are reassigned here as Arthricocephalus chauveaui. The specimens illustrated by McNamara et al. (2003), from Palang, Duyun, southeastern Guizhou, are all meraspid exoskeletons; the largest one has only seven thoracic segments (McNamara et al., 2003, pl. 2, fig. 4; Fig. 5.8). In one exoskeleton assigned to A. xinzhaihenesis by Yuan et al. (2006), the glabellar furrows S1-S3 are transglabellar and reach to the axial furrows. This character is regarded as indicative of A. chauveaui.

Shen et al. (2016) referred numerous specimens to the genus Arthricocephalites, either as Arthricocephalites xinzhaihenesis or as A. intermedius. Most of these specimens, in fact, represent Arthricocephalus chauveaui because their glabellar furrows S1 through S3 are transglabellar.

Arthricocephalites (Arthricocephalites) sp. 2 (Zhang et al., 1980, pl. 93, fig. 8) is questionably assigned to Arthricocephalus. It has a glabella with pit-like glabellar furrows and a fulcrate thorax with facets. However, the interpleural furrows in the pygidium are clearly incised, making it difficult to confidently assign the specimen to a certain species.

As discussed above, S1 through S3 are isolated from the axial furrows in Arthricocephalus xinzhaihenesis, unlike the transglabellar development of S1 through S3 in Arthricocephalus chauveaui. In oryctocephalids, the nature of S1 through S3 appears to be a critical specific character. In addition, the palpebral lobes and ocular ridges of $A$. xinzhaihenesis are more obliquely directed to the length of axis than those of $A$. chauveaui, suggesting that $A$. xinzhaihenesis is a species separate from A. chauveaui. However, the differences between both species in other features seem minimal, and both species share almost the same stratigraphic occurrences as well. For these reasons, the possibility that they represent sexual dimorphs of a single species can not be ruled out.

\section{Genus Oryctocarella Tomashpolskaya and Karpinski, 1961}

1961 Oryctocarella Tomashpolskaya and Karpinski, p. 156. 1988 Arthricocephalus Bergeron; Lane et al., p. 555 (part). 
Type species.-Oryctocara sibirica Tomashpolskaya in Khalfin, 1960 (p. 199, pl. 23, fig. 5), from the lower part of the traditional middle Cambrian, Batenevsky Ridge, Kuznetsk Alatau, Altay-Sayan Foldbelt, Russia; by original designation.

Other species.-Arthricocephalus duyunensis Qian, 1961 (p. 97, pl. 1, fig. 19, pl. 2, figs. 5, 7-10; non pl. 1, fig. 20, pl. 2, fig. 6 [ = Arthricocephalus chauveaui Bergeron, 1899]), from the Balang Formation, Palang, Duyun, eastern Guizhou, China; Arthricocephalus (Arthricocephalites) balangensis Qian and Lin in Yin and Li, 1978 (p. 442, pl. 157, fig. 10), from the Balang Formation, Palang, Duyun, eastern Guizhou, China.

Diagnosis.-Micropygous genus of Oryctocarinae with gently curved or transverse anterior margin, surface sculpture granulated or smooth. Glabella subrectangular to cylindrical, defined laterally by nearly straight axial furrows; S1-S4 pit-like or narrow incision, with $\mathrm{S} 1-\mathrm{S} 3$ distant from axial furrow, connected by weak or faint transverse furrows. Palpebral lobe notably oblique, located near or anterior to glabellar mid-length, palpebral area subequal in width with glabella. Facial suture proparian. Thorax non-fulcrate, consisting of 9-11, or rarely 12, segments; axis about half as wide as pleural region. Pygidium much shorter than cranidium, axis about half of pygidial length, with three rings and a tiny terminal piece; interpleural furrows well defined; borders absent, margin may have a posteromedial notch.

Remarks.-Oryctocarella is here regarded as a valid genus. Differences between the type species of Oryctocarella and Arthricocephalus are discussed at length above, and differences between $A$. chauveaui and $O$. duyunensis are illustrated in Figure 3. Oryctocarella is distinguished from Arthricocephalus in having a pygidium that is much shorter than the cephalon; a cylindrical glabella; pit-like glabellar furrows, most of which do not reach to the axial furrows; a larger number of thoracic segments; and well-defined interpleural furrows in the pygidium. In addition, the thoracic segments lack fulcra, and a pygidial border is not clearly developed in Oryctocarella.

Oryctocarella sibirica (Tomashpolskaya in Khalfin, 1960) Figure 6

1960 Oryctocara sibirica Tomashpolskaya in Khalfin, p. 199, pl. Cm-23, fig. 5.

1961 Oryctocarella sibirica; Tomashpolskaya and Karpinski, p. 156, pl. 1, figs. 1-6.
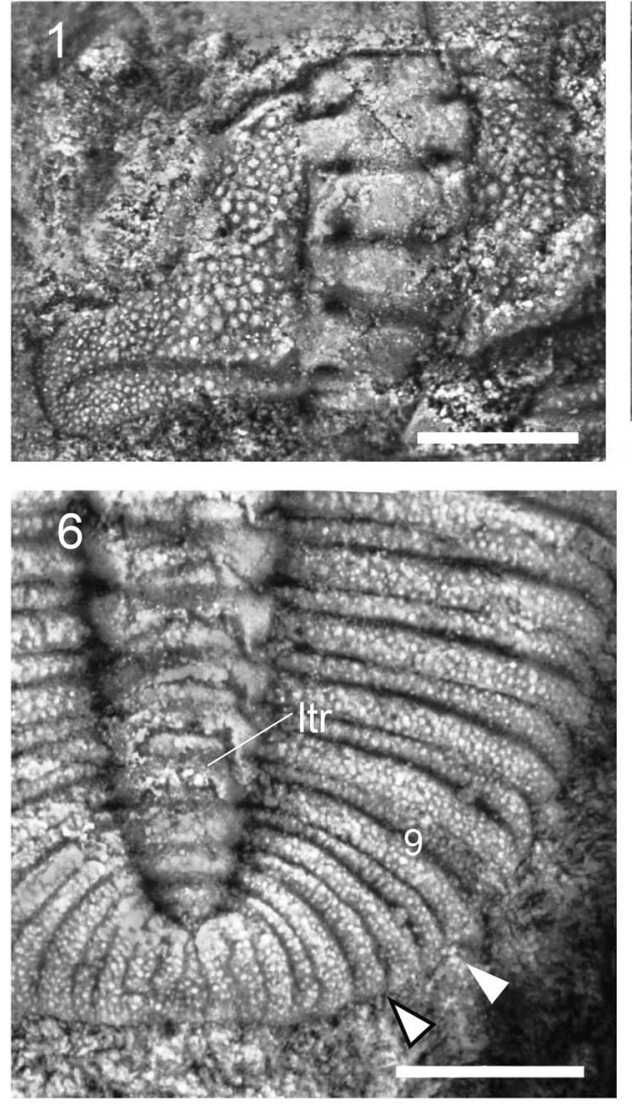
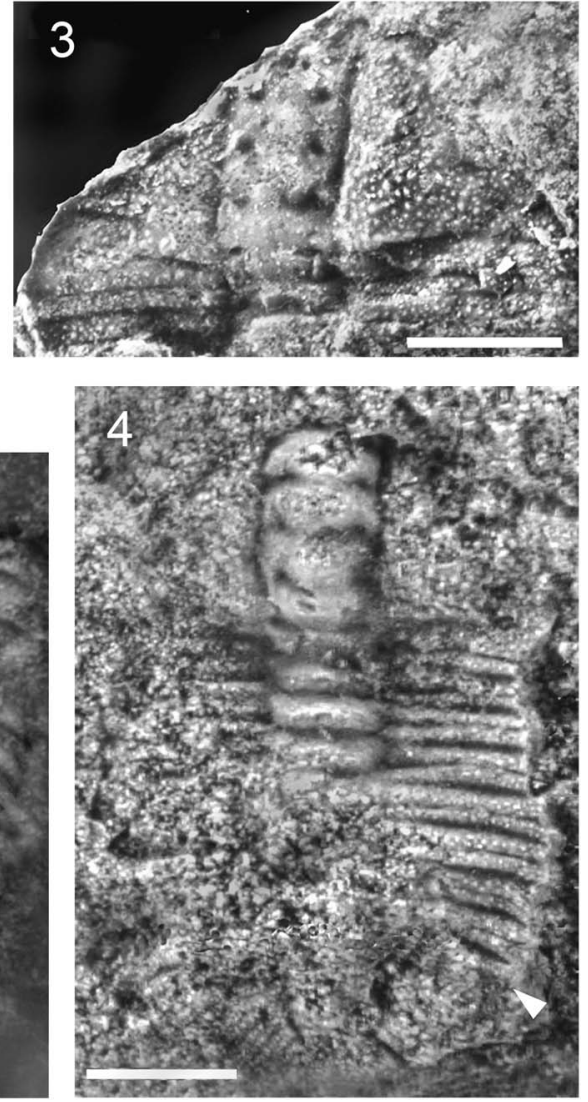

Figure 6. Oryctocarella sibirica (Tomashpolskaya in Khalfin, 1960), topotypes from the lower part of the Karasuk Formation, Region of Dolgii Mys range (DM), Kuznetsk Alatau, Altay-Sayan Foldbelt, Russia; all in dorsal view. White arrowhead indicates the posterior margin of thorax; arrowhead with black outline indicates the posterior margin of partially released segment of transitory pygidium; 1 tr $=$ last thoracic axial ring; $9=$ ninth thoracic segment: $(\mathbf{1})$ neotype CSGM2075/2, proposed here, incomplete cranidium, original specimen of Korovnikov and Novozhilova (2017, pl. 5, fig. 2); (2) CSGM2075/17, incomplete cranidium; (3) CSGM2075/16, latex cast from external mold of incomplete cranidium; (4) CSGM 2075/5, incomplete exoskeleton, meraspis degree 8, original specimen of Korovnikov and Novozhilova (2017, pl. 5, fig. 5); (5) CSGM2075/6, thoracopygon, holaspid?, with nine thoracic segments, original specimen of Korovnikov and Novozhilova (2017, pl. 5, fig. 6); (6) enlarged posterior part of CSGM2075/6 in 5, showing the broken last thoracic axial ring (ltr) on the ninth segment. All scale bars represent $1.0 \mathrm{~mm}$. 
2015 Oryctocarella sibirica; Peng et al., p. 89, pl. 1, fig. 5. 2017 Oryctocarella sibirica; Korovnikov and Novozhilova, p. 267, pl. 5, figs. 1-7; text-fig. 3.a, 3.b.

Neotype.-The original type material, including the holotype (an exoskeleton) and more than 10 additional variously complete exoskeletions, of which five were figured by Tomashpolskaya and Karpinski (1961, pl. 1, figs. 1, 3-6), is apparently lost. An incomplete cranidium, CSGM 2075/2 (Fig. 6.1) from a recent collection of topotypes, is designated as the neotype (see discussion below).

Diagnosis.-Oryctocarella with subrectangular or cylindrical glabella; preglabellar field absent; palpebral ridge faint, close to anterior border furrow; palpebral lobe located anterior to glabellar mid-length, with posterior tip opposite mid-length of L2 ( $34 \%$ of cephalic length); palpebral area narrower than glabella; posterior section of facial suture nearly transverse; cranidial posterior border widens abaxially. Thorax with nine segments; anterior pleural band equal to or slightly shorter than posterior band. Pygidial margin may have slight inward curvature medially, but lacks medial notch. Dorsal surface densely granulose.

Occurrence.-Known only from outcrop 863, Region of Dolgii Mys Mountain, Batenevsky Ridge, Kuznetsk Alatau, AltaySayan Foldbelt, southwestern Siberia, Russia; basal Amgan Stage (traditional middle Cambrian) of the Siberian regional stratigraphy, corresponding to the Cambrian Stage 4.

Materials.-Two unfigured cranidia (CSGM2075/16, CSGM 2075/17) and three specimens illustrated by Korovnikov and Novozhilova (2017), which include an incomplete cranidium (CSGM2075/2), an incomplete exoskeleton (CSGM2075/5), and a thoracopygon (CSGM2075/6); all in a single collection from the basal Amgan Stage of Siberian regional stratigraphy (provisional Cambrian Stage 4), Region of Dolgii Mys (Long Cape) Mountain, Batenevsky Ridge, Kuznetsk Alatau, AltaySayan Foldbelt, Russia, the type locality of the species.

Remarks.-The type species of Oryctocarella, Oryctocara sibirica, was originally based on a single exoskeleton, the holotype (Tomashpolskaya in Khalfin, 1960, p. 199, pl. 23, fig. 5, No. 863(1)58; refigured in Tomashpolskaya and Karpinski, 1961, pl. 1, fig. 2) from the traditional lower middle Cambrian,
Region of Dolgii Mys Mountain, Batenevsky Ridge, Kuznetsk Alatau, southwestern Siberia, Russia; by monotypy. When Tomashpolskaya and Karpinski (1961) erected the genus Oryctocarella, with Oryctocara sibirica as its type species, additional specimens from the same collection as the holotype were illustrated (Tomashpolskaya and Karpinski, 1961, pl. 1, figs. 1, 3-6). At least 10 variously complete exoskeletons were in the collection with the holotype (see Tomashpolskaya and Karpinski, 1961). The original material, which was housed at the Geological Museum of the Tomsk Polytechnic Institute (TPI, now Tomsk Polytechnic University), now appears to be lost. A search on our request by I. Korovnikov, Novosibirsk through the collections at Tomsk Polytechnic University, failed to recover any material of $O$. sibirica from Tomashpolskaya's original collection. Because of the absence of the original material, a neotype (Fig. 6.1) is selected from a collection of topotypes collected by I. Korovnikov from Tomashpolskaya's original locality in the Dolgii Mys Mountain region. This new material (Korovnikov and Novozhilova, 2017, pl. 5, figs. 1-7; Fig. 6), although not well preserved, is sufficient to demonstrate most morphological characters of $O$. sibirica, and that Oryctocarella should be regarded as a valid genus.

Oryctocarella sibirica was originally reported to have eight thoracic segments. One of the topotypes (Fig. 6.5, 6.6) shows that the thorax contains at least nine segments. In this specimen the axial ring of the ninth segment is present, but broken.

Differences between the type species of Oryctocarella, $O$. sibirica, and other species now referred to the genus, Oryctocarella balangensis (Qian and Lin in Yin and Li, 1978) and O. duyunensis (Qian, 1961), are discussed below.

Oryctocarella balangensis (Lu and Qian in Yin and Li, 1978) Figure 7

1961 Arthricocephalus duyunensis Qian (part), p. 97, pl. 1, fig. 20, pl. 2, fig. 6; non pl. 1, fig. 19, pl. 2, figs. 5, 7, 8, 10, ?fig. 9.

1978 Arthricocephalus (Arthricocephalites) balangensis $\mathrm{Lu}$ and Qian in Yin and Li, p. 442, pl. 157, fig. 10.

1980 Arthricocephalus (Arthricocephalites) xinzhaiheensis Qian; Zhang et al., p. 276, pl. 93, fig. 1; non pl. 92, figs. 5, 6.

1980 Arthricocephalus (Arthricocephalites) balangensis; Zhang et al., p. 277, pl. 93, figs. 2, 3.

1980 Arthricocephalus (Arthricocephalites) xiaosaiensis Qian in Zhang et al. (part), p. 278, pl. 93, fig. 7,

Figure 7. Oryctocarella balangensis (Lu and Qian in Yin and Li, 1978) from the Balang Formation in southeastern (1-3, 5) and eastern (4, 6-13) Guizhou, South China; all in dorsal view. White arrowhead indicates the posterior margin of thorax; arrowhead with black outline indicates the posterior margin of partially released segment of transitory pygidium; b = border, $d=$ doublure: (1) holotype NIGP 38240, incomplete exoskeleton, original of Lu and Qian in Yin and Li (1978, pl. 157, fig.10), GY210; (2) enlargement of part of cephalon in 1; (3) NIGP 38241, cephalon previously illustrated by Zhang et al. (1980, pl. 93, fig. 3), GY222; (4) NIGP 164947, incomplete cranidium on same slab as specimen in 8, XS-Xiao152; (5) NIGP 11485, cranidium previously illustrated by Qian (1961, pl. 1, fig. 20) as Arthricocephalus chauveaui, GY206; (6) NIGP 11492, cranidium previously illustrated by Qian (1961, pl. 2, fig. 6) as Arthricocephalus chauveaui, GY204; (7) NIGP 38239, cranidium previously illustrated by Zhang et al. (1980, pl. 93, fig. 1) as Arthricocephalus (Arthricocephalites) xinzhaiheensis, GY214; (8) NIGP 38244, cranidium previously illustrated by Zhang et al. (1980, pl. 93, fig. 7) as one of two 'holotypes' of Arthricocephalus (Arthricocephalites) xiaosaiensis Qian, retrodeformation with inferred strain ellipse, XS-Xiao152; (9) NIGP 38248, cranidium previously illustrated by Qian in Zhang et al. (1980, pl. 94, fig. 3) as one of two 'holotypes' of Arthricocephalus (Arthricocephalites) xiaosaiensis Qian, XS-Xiao152; (10) NIGP 38251, pygidium with six thoracic segments, previously illustrated by Zhang et al. (1980, pl. 94, fig. 6) as Arthricocephalus (Arthricocephalites) xiaosaiensis, XS-Xiao152; $(\mathbf{1 1}, \mathbf{1 3})$ NIGP 164948, external mold of incomplete exoskeleton, two views, reversed images, XS-Xiao152, in association with the pygidium in 10; (12) NIGP 164949, reversed image of external mold of thoracopygon, XS-Xiao152, on same slab as the NIGP 38251 pygidium in $\mathbf{1 0}$ and thoracopygon in $\mathbf{1 1 .}$ All scale bars represent $1.0 \mathrm{~mm}$. 

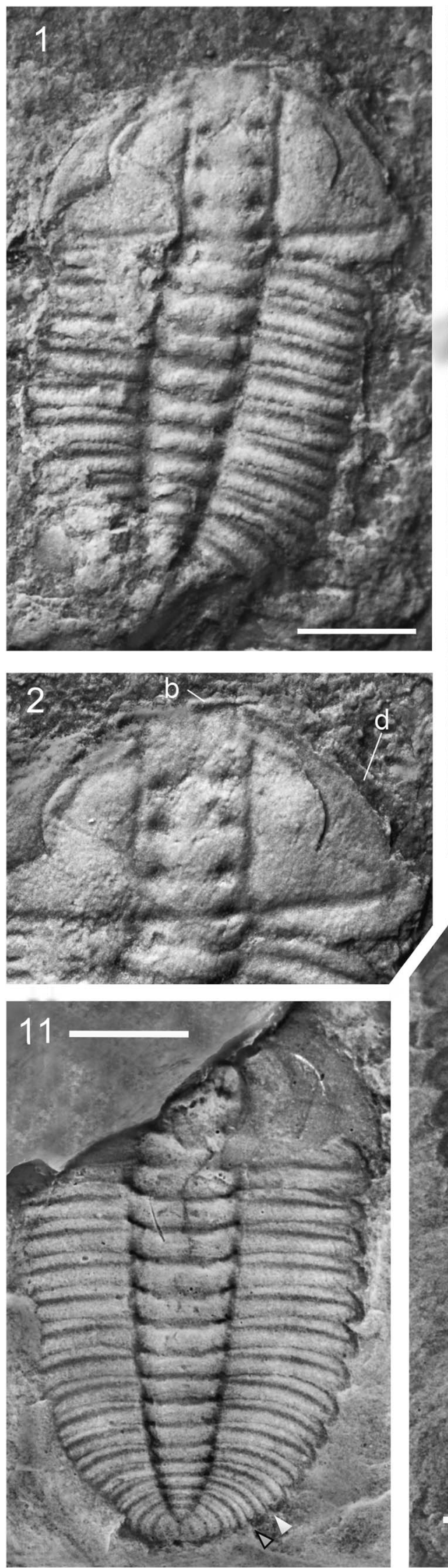
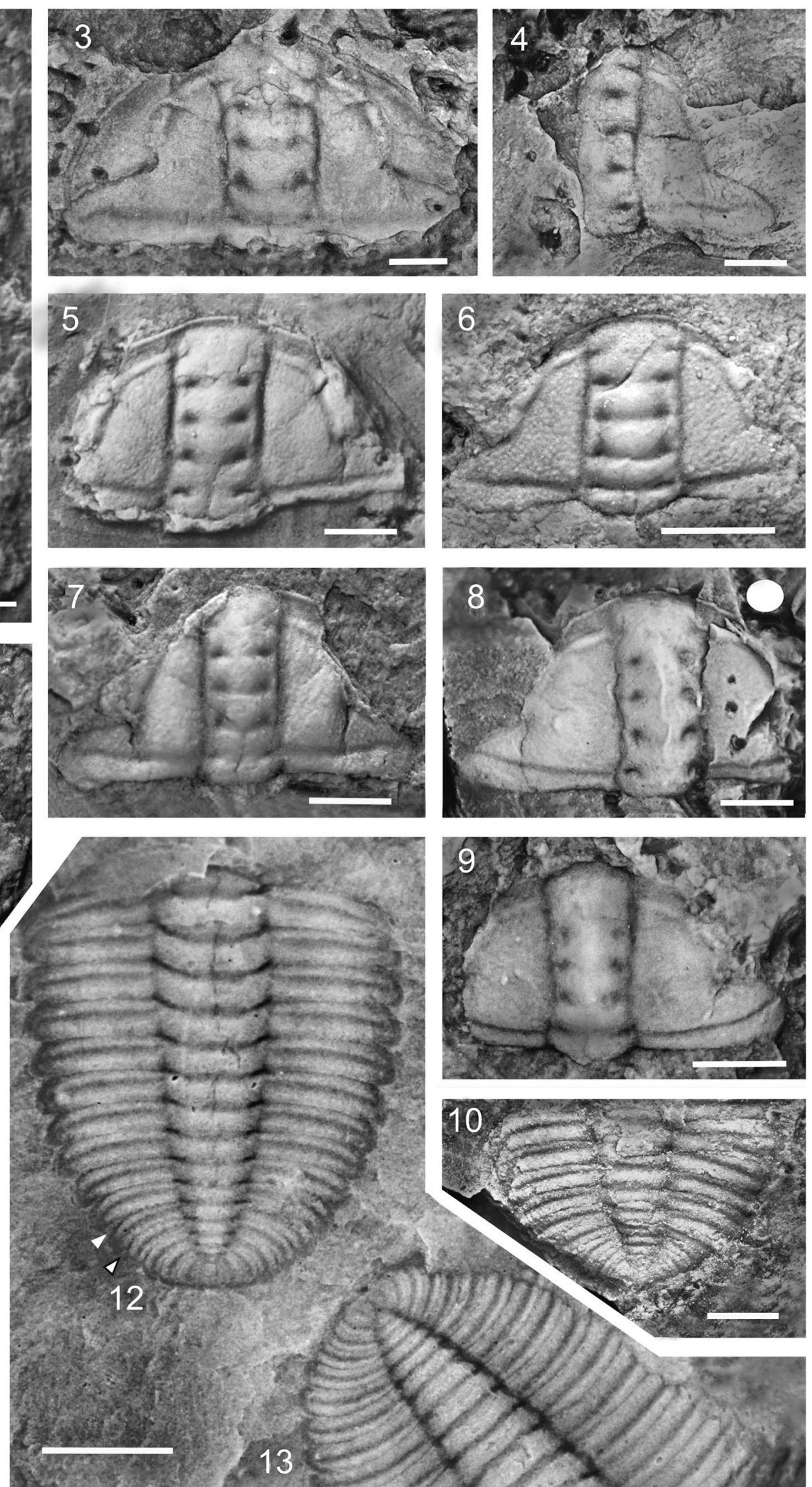

13 
pl. 94, figs. 3, 4, 6; non fig. 5 (? = Palaeolenus fengyanensis Zhu, 1962).

?2003 Arthricocephalus xinzhaiheensis; McNamara et al., p. 111 , pl. 2, figs. $1-4$, text-fig. 4A-D.

non 2003 Arthricocephalus balangensis; McNamara et al., p. 114, pl. 2, figs. $6,8,9$, text-fig. 5 .

Holotype.-Incomplete exoskeleton (Yin and Li, 1978, pl. 157, fig. 10, NIGP 38240; reillustrated by Zhang et al., 1980, pl. 93, figs. 2; Fig. 7.1, 7.2) from the Balang Formation, Palang, Duyun, southeastern Guizhou, China; by monotypy.

Diagnosis.-Oryctocarella with glabella subrectangular or cylindrical in outline; axial furrows parallel-sided or gently constricted medially; S0 and S1-S3 furrows pit-like, connected by faint transverse furrows; palpebral lobe located at about midlength of glabella, $\sim 0.29-0.31(\mathrm{~N}=6)$ of cephalic length, posterior end opposite posterior one-third of $\mathrm{L} 2$; palpebral ridge close to anterior cranidial border furrow; posterior branch of facial suture cutting lateral cephalic border opposite S1 or midlength of L1. Thorax non-fulcrate, with 11 or possibly 12 segments; axis three-quarters width of pleural region. Pygidial axis composed of three rings and a tiny terminal piece; posterior margin without a medial notch. Dorsal surface smooth or covered with fine granules.

Occurrence.-From yellow-green calcareous shale in the middle part of the Balang Formation, eastern Guizhou, South China (Jiangnan Slope Belt); Cambrian Stage 4, Duyunian Stage of the regional stratigraphic scheme.

Materials.-Three associated sclerites (unfigured), including an incomplete exoskeleton, a thoracopygon, and an incomplete cranidium (NIGP 164947-164949), from the Balang Formation near Xiaosai, Yuqing, eastern Guizhou, South China; refigured sclerites including the incomplete holotype exoskeleton of Arthricocephalus (Arthricocephalites) balangensis (Lu and Qian in Yin and Li, 1978) (NIGP 38240); a cephalon illustrated as Arthricocephalus (Arthricocephalites) balangensis by Zhang et al., 1980 (NIGP 38241); two cranidia assigned as Arthricocephalus chauveaui by Qian, 1961 (NIGP 11485, NIGP 11492); three incomplete cranidia, one of them assigned to Arthricocephalus (Arthricocephalites) xinzhaiheensis by Qian in Zhang et al., 1980 (NIGP 38239), and two "holotypes" designated for the new species Arthricocephalus (Arthricocephalites) xiaosaiensis Qian in Zhang et al., 1980 (NIGP 38244, NIGP 38248); one pygidium assigned as Arthricocephalus (Arthricocephalites) xiaosaiensis Qian in Zhang et al., 1980 (NIGP 38251); and an unfigured incomplete cranidium in association with NIGP 38244.

Remarks. - This species, originally introduced as Arthricocephalus (Arthricocephalites) balangensis, is now transferred to Oryctocarella. It was referred to Arthricocephalus (Arthricocephalites) principally because its glabella was thought to be expanded forward anterior to S4 (Yin and $\mathrm{Li}, 1978$, p. 442; Zhang et al., 1980, p. 277). Our new observations indicate that this species does not belong to A. (Arthricocephalites) (a junior synonym of Arthricocephalus), but to Oryctocarella. Examination of the holotype (Fig. 7.1, 7.2) shows that the glabella is subrectangular in outline, defined by nearly straight axial furrows, and is not expanded anteriorly. A cephalon illustrated by Zhang et al. (1980, pl. 93, fig. 3; Fig. 7.3) indicates an expansion of the anterior part of the glabella, but this is clearly an artefact of compaction. The axial furrows on this specimen are not symmetrical to the axis, providing evidence of differential distortion.

Other characters further support assignment of this species to Oryctocarella. The thorax of this species was originally described as having at least 10 segments. However, new material shows that the thorax consists of eleven, or possibly twelve segments (Fig. 7.11, 7.12). The thoracic segments lack clear fulcra. This species is better characterized by pit-like glabellar furrows that are separated from the axial furrows, but connected by faint to obsolescent transverse furrows. The occipital furrow is weak and deepens into pits in a short distance before reaching to the axial furrow. The facial suture is proparian.

This species shows variability in surface sculpture. Most specimens do not show a prosopon. One cephalon (Fig. 7.3) assigned to the species by Zhang et al. (1980, pl. 93, fig. 3), and two cranidia (Fig. 7.5, 7.6), previously assigned to A. chauveaui by Qian (1961, pl. 1, fig. 20, pl. 2, fig. 6), bear fine, densely spaced granules.

Exoskeletons of meraspides referred to Arthricocephalus xinzhaiheensis by McNamara et al. (2003, pl. 2, figs. 1-4) are questionably assigned to Oryctocarella balangensis herein. The largest of these specimens (McNamara et al., 2003, pl. 2, fig. 4) is of a meraspid degree 8 . It has a cylindrical glabella with pitlike S1-S4, a proparian facial suture (with the right hand librigena somewhat displaced), and a relatively broad thoracic axis. All these features are consistent with assignment to $O$. balangensis. However, the interpleural furrows in the pygidium are poorly defined, and this character is more reminiscent of Arthricocephalus.

Two cranidia (Fig. 7.5, 7.6), previously assigned to Arthricocephalus chauveaui by Qian (1961, pl. 1, fig. 20, pl. 2, fig. 6), are here transfered to $O$. balangensis. They were collected from the same section as the holotype of A. balangensis at Palang, Duyun, and are morphologically indistinguishable from the cranidium of the holotype. McNamara et al. (2003, p. 114) correctly referred these cranidia to Arthricocephalus balangensis (now $O$. balangensis), although those authors used a broader concept for A. balangensis, which included some specimens (McNamara et al., 2003, pl. 2, figs. 6, 8, 9) here reassigned to Arthricocephalus xinzhaiheensis.

A cranidium from the Balang Formation at Palang, which was assigned to Arthricocephalus (Arthricocephalites) xinzhaiheensis by Zhang et al. (1980, pl. 94, fig. 1; Fig. 7.7) apparently suffered transverse compression and is also included in $O$. balangensis herein.

Arthricocephalus (Arthricocephalites) xiaosaiensis Qian in Zhang et al., 1980 (p. 278, pl. 93, fig. 7, pl. 94, figs. 3-6; Fig. 7.8-7.10), from the Xiaosai section, Yuqing, eastern Guizhou, is a junior synonym of $O$. balangensis because the morphology of its doubly designated 'holotype' cranidia falls within the morphological plasticity of the cranidia of $O$. balangensis. The non-fulcrate thorax and micropygous pygidium in the incomplete thoracopygon that is associated with the 'holotypes' (Zhang et al., 1980, pl. 94, fig. 6; Fig. 7.10) 
also show that the species belongs to Oryctocarella. Additional figured specimens of the species (Fig. 7.11-7.13) from the same collection show a non-fulcrate thorax and micropygous pygidium as well.

One thoracopygon from the Xiaosai section, eastern Guizhou (Zhang et al., 1980, pl. 94, fig. 5) is not conspecific with other specimens assigned to A. (Arthricocephalites) xiaosaiensis $(=O$. balangensis $)$ because of the presence of fulcra in the thoracic segments. This specimen is tentatively reassigned to Palaeolenus fengyanensis Zhu, 1962, a species that co-occurs with $O$. balangensis in collection XS-Xiao152 (Zhang et al., 1979, p. 92).

Oryctocarella balangensis resembles $O$. sibirica in the shape of the glabella, the morphology of the glabellar furrows, and the location of the palpebral lobe. It differs from the type species of the genus in having less well defined transverse furrows in the medial area of the glabella, and in having a smooth or finely granulated dorsal surface. These characters also differentiate $O$. balangensis from $O$. duyunensis, which bears a strong and dense granulation. Among these three species, only $O$. duyunensis is known to have a distinct posteromedial notch on the pygidial margin. Other, more subtle characters that seem to differentiate $O$. balangensis from $O$. sibirica are a more clearly defined palpebral ridge and a less divergent posterior branch of the facial suture in the former species.

Oryctocarella duyunensis (Qian, 1961)

Figures 1.1-1.7, 2.4-2.9, 3.2, 8, 9

1961 Arthricocephalus duyunensis Qian (part), p. 97, pl. 1, fig. 19, pl. 2, figs. 5, 7, 8, 10, ?fig. 9; non pl. 1, fig. 20, pl. 2, fig. 6.

1964 Arthricocephalus chauveaui Bergeron, 1899; Lu and Qian, p. 26, pl. 1, fig. 5.

1965 Arthricocephalus duyunensis; Lu et al., p. 108, pl. 17, figs. 2, 3, 5, non 4.

1974 Arthricocephalus duyunensis; Lu et al., p. 95, pl. 36, fig. 9.

1977 Arthricocephalus granulus Qian and Lin in Zhou et al., p. 130, pl. 42, figs. 1,2 .

1977 Arthricocephalus chauveaui; Zhou et al., p. 130, pl. 42, fig. 3.

1978 Arthricocephalus duyunensis; Yin and Li, p. 440, pl. 155, fig. 10.

1978 Arthricocephalus jiangkouensis Yin in Yin and $\mathrm{Li}$, p. 440, pl. 155, figs. 15,16 .

1978 Arthricocephalus (Arthricocephalites) granulus Qian and Lin; Yin and Li, p. 441, pl. 157, fig. 2.

1980 Arthricocephalus chauveaui; Zhang et al., p. 275, pl. 92, figs. 1, 2.

1980 Arthricocephalus horridus Qian and Lin in Zhang et al., p. 275, pl. 92, figs. 7-9.

1980 Arthricocephalus (Arthricocephalites) granulus; Zhang et al., p. 277, pl. 90, fig. 8, pl. 93, fig. 4, pl. 94, figs. 1, 2.

1982 Arthricocephalus granulus; Liu, p. 300, pl. 214, figs. $1,9$.

?1983 Arthricocephalus (Arthricocephalites) granulus; Ju, p. 632 , pl. 2, figs. 12, 13.
1983 Arthricocephalus (Arthricocephalites) sp., Ju, pl. 2, figs. $14,15$.

?1985 Arthricocephalus tenuis Zhang and Zhou, p. 263, pl. 2, figs. 10-12.

1985 Arthricocephalus duyunensis; Zhang and Zhou, p. 263, pl. 2, figs. 8, 9.

1985 Arthricocephalus sp., Zhang and Zhou, p. 263, pl. 2, fig. 14.

1988 Arthricocephalus chauveaui; Lane et al. (part), p. 555, pl. 1, figs. 2, 3, 6; non figs. 1, 4, 5 .

1997 Arthricocephalus chauveaui; Blaker and Peel (part), p. 112, figs. 62.2, 62.3, 63, 64.1-64.4; non fig. 62.1.

2001a Arthricocephalus granulus; Zhao et al., p. 180, pl. 1, figs. 4-6.

2002 Arthricocephalus chauveaui; Yuan et al., p. 121, pl. 31, fig. 1.

2003 Arthricocephalus chauveaui; McNamara et al., p. 106, pl. 1, figs. 1-15, pl. 2, figs. 5, 7, text-fig. 3A-K.

2005 Arthricocephalus chauveaui; Geyer, 2005 (part), p. 87, fig. 3.1-3.4, 3.8, 3.9; non fig. 3.7.

2005a Arthricocephalus chauveaui; Peng et al., p. 1161, fig. 2e.

2005b Arthricocephalus chauveaui; Peng et al., p. 1056, fig. 2e.

2006 Arthricocephalus chauveaui; Yuan et al., p. 615, fig. 1d, 1e.

2006 Arthricocephalus chauveaui; Peng et al., p. 241, pl. 1, fig. 11.

2006 Arthricocephalus granulus; Yuan et al., p. 616, fig. 1b, 1c.

2006 Arthricocephalus jiangkouensis; Yuan et al., fig. 1a.

2011 Arthricocephalus cf. chauveaui; Geyer and Peel, p. 498, fig. 14A-C, D?, E, F.

2015 Oryctocarella duyunensis; Peng et al., p. 89, pl. 1, figs. 6-9.

Holotype.-Incomplete exoskeleton (Qian, 1961, pl. 2, fig. 8; Fig. 8.17, NIGP 11484) from the Balang Formation, Palang, Duyun, eastern Guizhou, China; by original designation.

Diagnosis.-Oryctocarella with subcylindrical glabella; axial furrows with subparallel sides or gently diverging forward; palpebral ridge well defined, preocular field short or absent; palpebral lobe in anterior position, with posterior tip in adult specimens opposite midlength or anterior part of L2; palpebral area subequal in width to glabella. Thorax with 11 or possibly 12 segments; axis about half as broad as pleural region; anterior pleural band shorter than posterior band. Pygidial axis composed of three rings and a terminal piece; posterior margin with a medial notch. Surface covered with densely spaced granules.

Occurrence.-From dark-gray calcareous mudstone and shale (weathering yellow-green) in the lower and middle parts of the Balang Formation, eastern Guizhou, and western Hunan, South China (Jiangnan Slope Belt); Cambrian Stage 4, Duyunian Stage of the regional stratigraphic scheme. It also occurs in the Olenellus Zone-equivalent of the Henson Gletscher Formation, North Greenland (Cambrian Stage 4). 

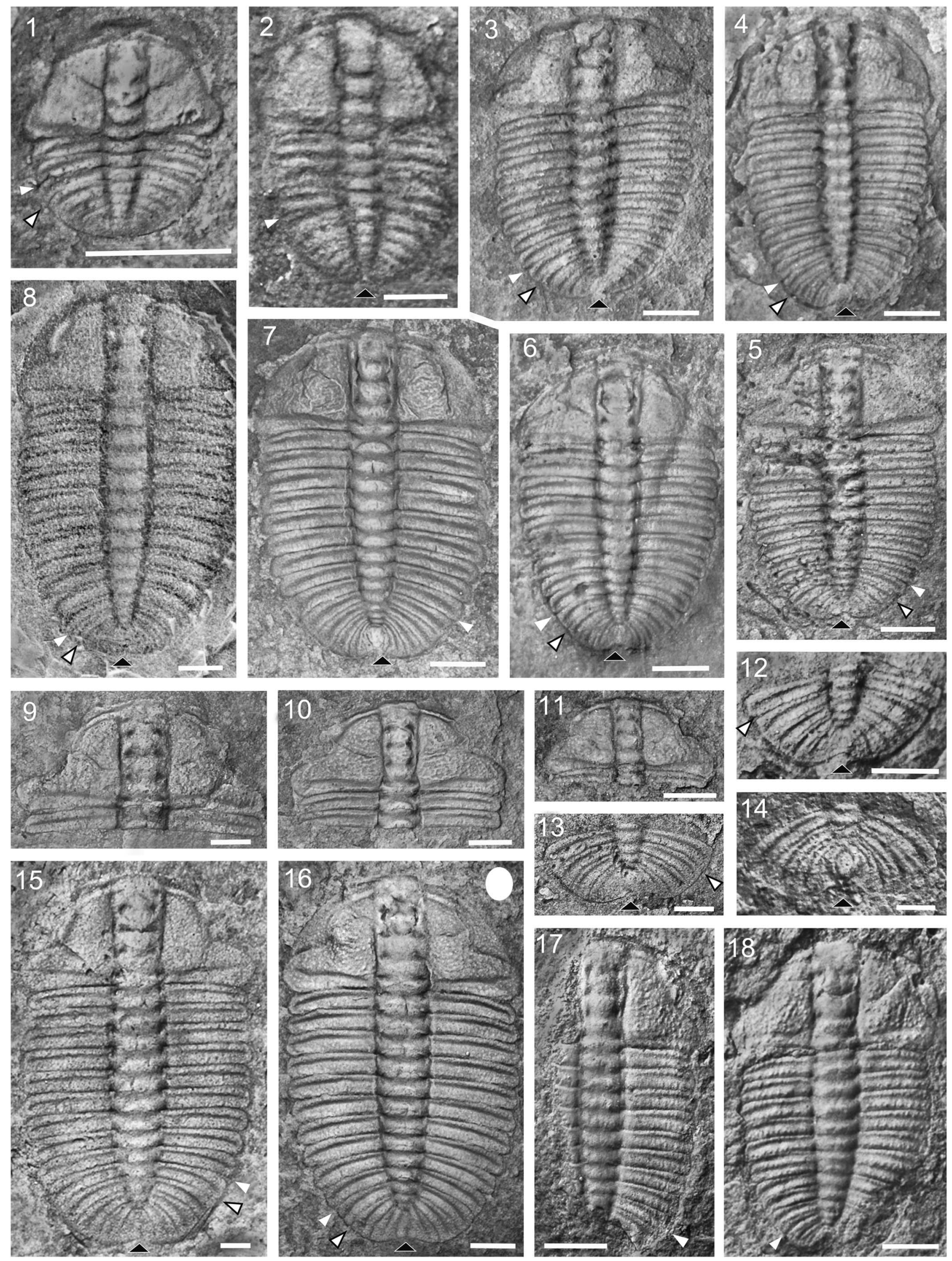
Description.-Exoskeleton elliptic in outline, about twice as long as wide. Cephalon subsemicircular in outline, with rounded genal corners; glabella subcylindrical, about four times as long as broad, widest part generally across L4; axial furrow more or less straight, parallel-sided or faintly divergent forward to near glabellar front; occipital furrow weak, deepened at lateral ends as incisions. Four pairs of glabellar furrows present; S1-S3 pitlike, each pair connected by a weak or faint transverse furrow that stops within pit, without extending outward to reach axial furrows; S4 narrow incision reaching to axial furrow abaxially; occipital ring wider, but much shorter than L1; L1-L3 subequal in length; L4 shorter than L3, and frontal lobe shorter than L4; L4 plus frontal lobe slightly longer than L3. Palpebral lobe mediumsized, $\sim 0.26-0.31$ ( $\mathrm{N}=11$ ) of cephalic length in adult specimens, gently curved, about $40^{\circ}$ oblique to sagittal line, lying anterior to glabellar mid-length, posterior tip opposite S2; palpebral area about as wide as glabella or slightly narrower. Anterior branch of facial suture short, with straight posterior portion, moderately convergent and curved in anterior portion; posterior branch diverging outward and somewhat rearward, meeting lateral cephalic margin opposite L1. Librigena narrow, with wire-like, poorly defined lateral border; somewhat upturned posteriorly and progressively elevated anteriorly to merge with upturned anterior border of cranidium. Anterior cranidial border furrow well defined; posterior cephalic border transverse, broadening abaxially; posterior border furrow well defined.

Hypostome (Fig. 9.17, 9.18) subovate with inflated middle body and broad lateral and posterior borders, posterior margin gently curved, anterior margin (?hypostomal suture) horizontal.

Thorax non-fulcrate, with 11 or possibly 12 segments. Axis about half as broad as pleural region, gently narrowing rearward, slightly expanded medially, widest at segments 3-6; pleura with obtusely rounded tip, unequally divided into a shorter (exsag.) anterior band and a longer (exsag.) posterior band by well-incised pleural furrow, which runs slightly oblique to the longitudinal direction of the pleura and shows a weak rearward swing near abaxial termination.

Pygidium in holaspis (Fig. 8.14) subelliptical, transverse, about twice as broad as long. Axis small, containing a prominent articulating half-ring, three rings and a terminal piece, tapering rapidly rearward, occupying about half of pygidial length; ring furrows weakly to moderately defined. Pleural region gently convex, with 3-4 pleurae; pleural furrows and interpleural furrows well defined, gently curved; interpleural furrows slightly less well developed than pleural furrows. Posterior margin with a medial notch.

Dorsal surface covered with densely spaced granules.
Materials.-Hundreds of sclerites from three sections (Mozichong, Bulin and Paiwu), Huayuan, northwestern Hunan, of which 22 exoskeletons (NIGP 164844-164851; NIGP 164858-164870; NWU-DYXJT 1823), three cranidia (NIGP 164852-164854) and three pygidia (NIGP164855-164857) are illustrated; reillustrated specimens include the holotype exoskeleton of the species (NIGP 11494) and an exoskeleton designated as holotype of Arthricocephalus horridus Qian and Lin in Zhang et al., 1980 (NIGP 38236).

Remarks.-Oryctocarella duyunensis was originally referred to Arthricocephalus (Qian, 1961). Lane et al. (1988) regarded the species as a junior synonym of $A$. chauveaui, and selected a 'lectotype' for A. chauveaui (suppressed here) that in fact belongs to $O$. duyunensis. For three decades, the concepts of Arthricocephalus and A. chauveaui were thus based on specimens that are here referred to $O$. duyunensis. As discussed above and summarized in Figure 3, this species differs significantly from $A$. chauveaui. This species is similar to Oryctocarella sibirica (Tomashpolskaya in Khalfin, 1960) (Fig. 6), the type species of Oryctocarella. In O. duyunensis, the palpebral lobe is located somewhat more anteriorly, and its posterior tip is opposite $\mathrm{S} 2$, whereas in $O$. sibirica the posterior tip of the palpebral lobe is opposite L2, and as a result, it appears to have more strongly diverging posterior branches of the facial suture. The neotype of $O$. sibirica (Fig. 6.1) and some other cranidia (Fig. 6.2, 6.3) differ from O. duyunensis in its glabellar shape (being subrectangular rather than cylindrical) and proportion (glabellar length ranging up to three times its width). There is considerable variability in these characters among the topotype material (Korovnikov and Novozhilova, 2017, pl. 5, figs. 1, 3; Fig. 6.2, 6.3), but O. duyunensis differs further in having 11 or 12 thoracic segments in the holaspid stage and bearing a distinct posteromedial notch in the pygidial margin, whereas $O$. sibirica has only nine or possibly 10 thoracic segments, and evidently lacks a distinct posteromedial notch in the pygidial margin.

Genus Duyunaspis Zhang and Qian in Zhou et al., 1977

1977 Duyunaspis Zhang and Qian in Zhou et al., p. 131. 1988 Arthricocephalus Bergeron; Lane et al. (part), p. 555.

Type species.-Duyunaspis duyunensis Zhang and Qian in Zhou et al., 1977, p. 132, pl. 41, figs. 5, 6, from the Balang Formation, Palang, Duyun, southeastern Guizhou; by original designation.

\footnotetext{
Figure 8. Oryctocarella duyunensis (Qian, 1961) from the Balang Formation in northwestern Hunan (1-15) and eastern Guizhou (16-18), China; all in dorsal view. White arrowhead indicates the posterior margin of thorax; arrowhead with black outline indicates the posterior margin of partially released segment of transitory pygidium; black triangle indicates medial notch at pygidial margin. (1) NIGP 164844, exoskeleton, meraspis degree 2, MZC-1; (2) NIGP 164845, exoskeleton, meraspis degree 4, MZC-1; (3) NIGP 164846, exoskeleton, meraspis degree 8, MZC-1; (4) NIGP 164847, exoskeleton, meraspis degree 9, MZC-1; (5) NIGP 164848, exoskeleton, meraspis degree 9, MZC-1; (6) NIGP 164849, exoskeleton, meraspis degree 9, MZC-1; (7) NIGP 164850, exoskeleton, meraspis degree 9, MZC-1; (8) NIGP 164851, exoskeleton, holaspid, thorax with possibly twelve segments, MZC-1; (9) NIGP 164852, cranidium with one thoracic segment, meraspis, MZC-1; (10) NIGP 164853, cranidium with two thoracic segments, meraspis, MZC-1; (11) NIGP 164854, cranidium with one thoracic segment, meraspis, MZC-1; (12) NIGP 164855, transitory pygidium with the anterior segment almost completely released, MZC-1; (13) NIGP 164856, transitory pygidium with the anterior segment partly released, MZC-1; (14) NIGP 164857, pygidium, holaspid, MZC-1; (15) NIGP 164858, exoskeleton, meraspis degree 9, MZC-1; (16) NIGP 38246, exoskeleton, meraspis degree 10, holotype of Arthricocephalus granulus Qian and Lin in Zhou et al., 1977 (pl. 42, fig. 2), retrodeformation with inferred strain ellipse, KH020; (17) holotype NIGP 11494, exoskeleton, meraspis degree 9, originally assigned as Arthricocephalus duyunensis Qian, 1961 (pl. 2, fig. 8), GY207; (18) NIGP 38236, exoskeleton, meraspis degree 9, holotype of Arthricocephalus horridus Qian and Lin in Zhang et al., 1980 (pl. 92, fig. 7), GY203. All scale bars represent $1.0 \mathrm{~mm}$.
} 

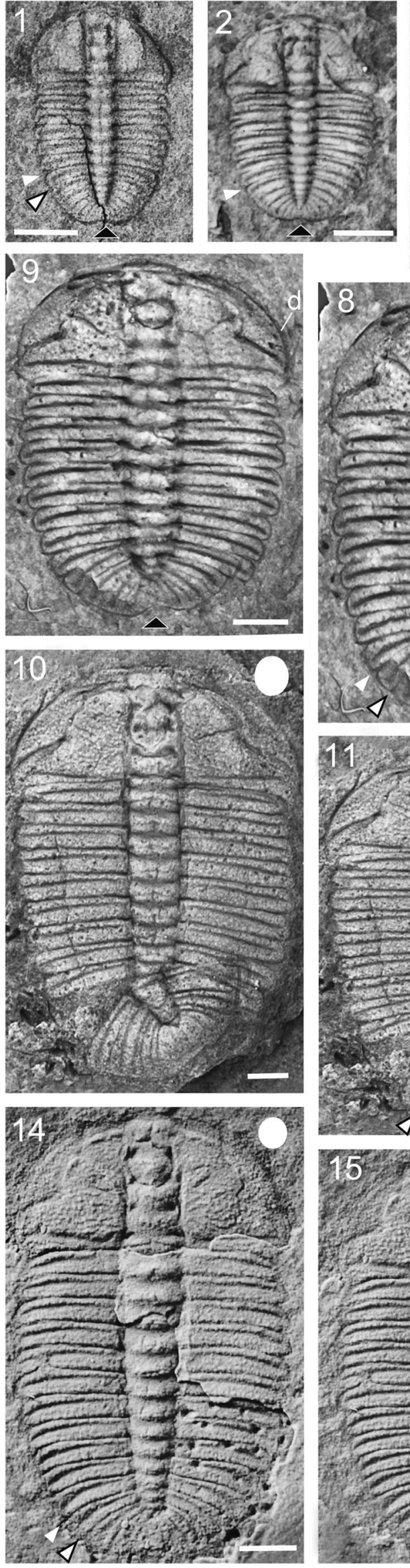
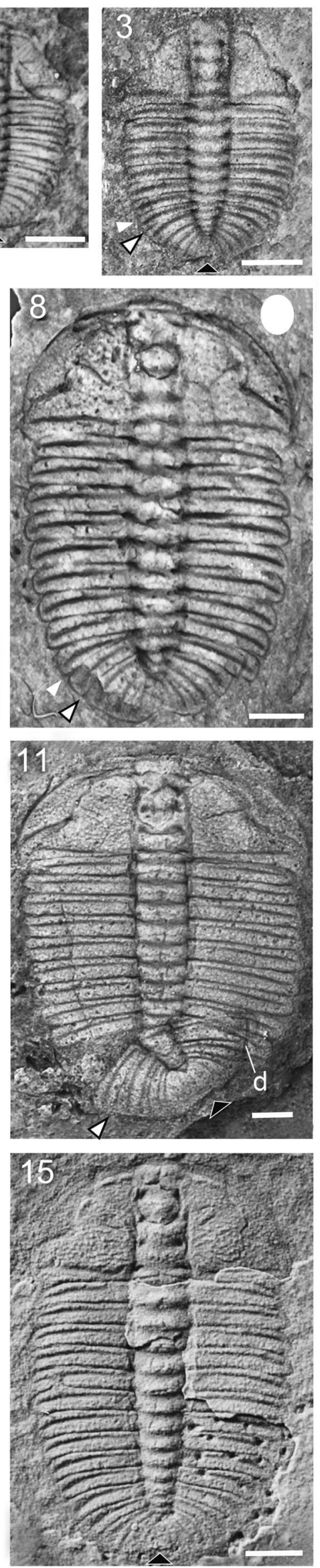
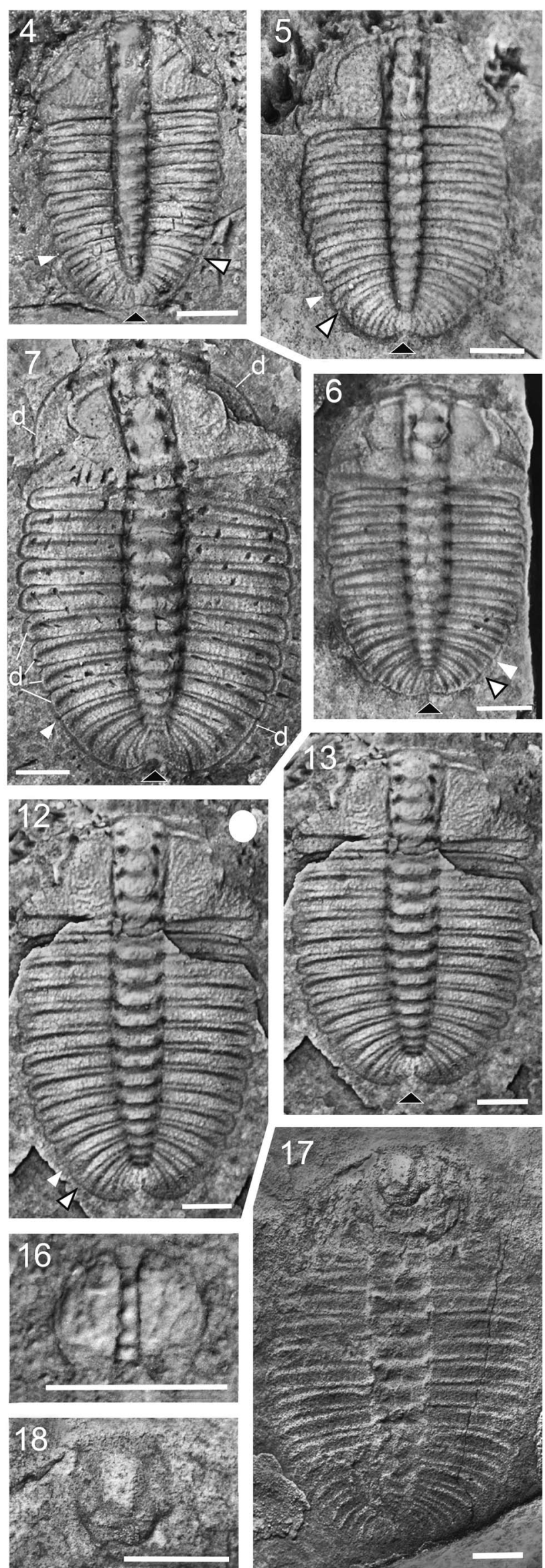
Other species.-Duyunaspis paiwuensis Lei and Peng, 2014 (p. 357, figs. 4, 5a), from the Balang Formation, Paiwu, Huayuan, northwestern Hunan.

Diagnosis.-Micropygous genus of the Oryctocarinae with large, broadly subrectangular glabella; glabellar furrows present or absent, connected or separated from axial furrow; palpebral lobe long, occupying nearly half of glabellar length; palpebral field narrow, less than half of glabellar width. Thorax fulcrate, with nine segments; thoracic axis about as wide as pleural region; fulcrum located about one-third distance from axial furrow. Pygidium broad and short, axis with three rings plus a terminal piece; interpleural furrows poorly defined; lateral and posterior border poorly defined; posteromedial notch on margin commonly present. Dorsal surface smooth or covered with fine granules.

Remarks.-McNamara et al. (2006) and Lei and Peng (2014) discussed Duyunaspis in detail. Two species assigned to this genus are considered properly recognizable: Duyunaspis duyunensis and D. paiwuensis Lei and Peng, 2014 (p. 357, fig. 4). Lei and Peng (2014) provided an expanded concept of the genus, and that concept is followed here. Five species described from the Balang Formation in either northwestern Hunan or eastern Guizhou, South China, have been assigned to Duyunaspis, but, upon review by Lei and Peng (2014, p. 355), were determined to fall within the range of morphologic variation of $D$. duyunensis, and were therefore regarded as junior synonyms. We concur with that conclusion. The species are: (1) Duyunaspis guzhangensis Zhou (in Zhou et al., 1977, p. 132, pl. 41, fig. 7), based on a single exoskeleton collected from Guanba, Guzhang, northwestern Hunan; (2) Duyunaspis songtaoensis Qian and Lin (in Zhou et al., 1977, p. 132, pl. 41, fig. 8), based on a single exoskeleton from Xiunao, Songtao, eastern Guizhou; (3) Duyunaspis briaris Qian and Lin (in Yin and $\mathrm{Li}, 1978$, p. 445, pl. 156, fig. 4), based on a single cranidium from Xiunao, Songtao, eastern Guizhou; (4), Duyunaspis obesis Qian and Lin (in Zhang et al., 1980, p. 274, pl. 90, fig. 6), which is an objective junior synonym of $D$. briaris because both species are based on the same holotype cranidium; and (5) Duyunaspis laevigatus Qian and Lin (in Zhang et al., 1980, p. 274, p. 91, figs. 7-9), known from three exoskeletons collected from Xiunao, Songtao, eastern Guizhou.

As discussed above, the smallest exoskeleton in Bergeron's type series of Arthricocephalus chauveaui (Figs. 1.8, 2.12) is conspecific with $D$. duyunensis.

Duyunaspis was diagnosed by McNamara et al. (2006, p. 7) as having seven thoracic segments and five pygidial rings. New material illustrated both here and by Lei and Peng (2014), from the Balang Formation at Mozichong and Paiwu, Huayuan, northwestern Hunan, shows that holaspides have nine thoracic segments and three rings in the pygidial axis, indicating that all exoskeletons illustrated by McNamara et al. (2006) represent meraspid degree 7 individuals.

Duyunaspis is easily differentiated from both Arthricocephalus and Oryctocarella by having a proportionately broader glabella, a narrower fixigena, less well defined glabellar furrows, a longer palpebral lobe, and a broader thoracic axis. Each of the three genera can be distinguished by the number of thoracic segments in holaspides. Duyunaspis has nine thoracic segments, Arthricocephalus has eight thoracic segments and Oryctocarella has 11 or 12 thoracic segments. Both Duyunaspis and Arthricocephalus have fulcrate thoraxes, but the fulcra in Duyunaspis lie closer to the axial furrow than in Arthricocephalus. Oryctocarella differs from both Duyunaspis and Arthricocephalus in lacking fulcra. Both Duyunaspis and Oryctocarella are micropygous, whereas Arthricocephalus is isopygous. Species of Duyunaspis and Oryctocarella commonly show a posteromedial notch on the pygidial margin, but this characteristic is unknown in Arthricocephalus.

Duyunaspis duyunensis Zhang and Qian in Zhou et al., 1977 Figures 1.8, 2.12, 10

1977 Duyunaspis duyunensis Zhang and Qian in Zhou et al., p. 132, pl. 41, figs. 5, 6 .

1977 Duyunaspis guzhangensis Zhou in Zhou et al., p. 132, pl. 41 , fig. 7.

1977 Duyunaspis songtaoensis Qian and Lin in Zhou et al., p. 132 , pl. 41 , fig. 8 .

1978 Duyunaspis laevigatus Qian and Lin in Yin and Li, p. 444, pl. 156, fig. 3.

1978 Duyunaspis songtaoensis; Yin and Li, p. 444, pl. 156, fig. 5.

1978 Duyunaspis duyunensis; Yin and Li, p. 444, pl. 157, fig. 11.

1978 Duyunaspis braris Qian and Lin in Yin and Li, p. 445, pl. 156, fig. 4.

1980 Duyunaspis duyunensis; Zhang et al., p. 273, pl. 91, figs. 5, 6.

1980 Duyunaspis obesis Qian and Lin in Zhang et al., p. 274, pl. 90, fig. 6.

1980 Duyunaspis songtaoensis; Zhang et al., p. 274, pl. 90, fig. 7; pl. 91, fig. 2.

1980 Duyunaspis laevigatus; Zhang et al., p. 274, pl. 91, figs. 7-9.

1982 Duyunaspis songtaoensis; Liu, 1982, p. 299, pl. 212, fig. 18.

1982 Duyunaspis guzhangensis; Liu, p. 299, pl. 212, fig. 14.

Figure 9. Oryctocarella duyunensis (Qian, 1961) from the Balang Formation at Bulin and Mozichong, Huayuan, northwestern Hunan, China; all in dorsal views unless stated otherwise. White arrowhead indicates the posterior margin of thorax; arrowhead with black outline indicates the posterior margin of partially released segment of transitory pygidium; black triangle indicates posteromedial notch; $d=$ doublure: (1) NIGP 164859, exoskeleton, meraspis degree 6, BL-1; (2) NIGP 164860, exoskeleton, meraspis degree 7, BL-1; (3) NIGP 164861, exoskeleton, meraspis degree 7, BL-1; (4) NIGP 164862, exoskeleton, meraspis degree 7, BL-1; (5) NIGP 164863, exoskeleton, meraspis degree 9, MZC-2; (6) NIGP 164864, exoskeleton, meraspis degree 9, BL-1; (7) NIGP 164865, exoskeleton with detached cranidium, meraspis degree 9, BL-1; (8) retrodeformation of specimen in 9 with inferred strain ellipse; (9), NIGP 164866, exoskeleton, meraspis degree 10, BL-1; (10) retrodeformation of specimen in 11 with inferred strain ellipse; (11) NIGP 164867, exoskeleton, meraspis degree 9, BL-1; (12), retrodeformation of specimen in 13 with inferred strain ellipse; (13) NIGP 164868, exoskeleton, meraspis degree 9, BL-1; (14) retrodeformation of specimen in 15 with inferred strain ellipse; (15) NWU-DYXJT 1823, exoskeleton, holaspid, MZC-1; (16) NIGP 164869, metaprotaspis with distinctly divided axis, distinct eye ridge and dot-like palpebral lobe, BL-1; $(\mathbf{1 7}, \mathbf{1 8})$ NIGP 164870 , external mold of exoskeleton, ventral view, meraspis degree 10 (17), and enlargement of hypostome (18), BL-1. All scale bars represent $1.0 \mathrm{~mm}$. 

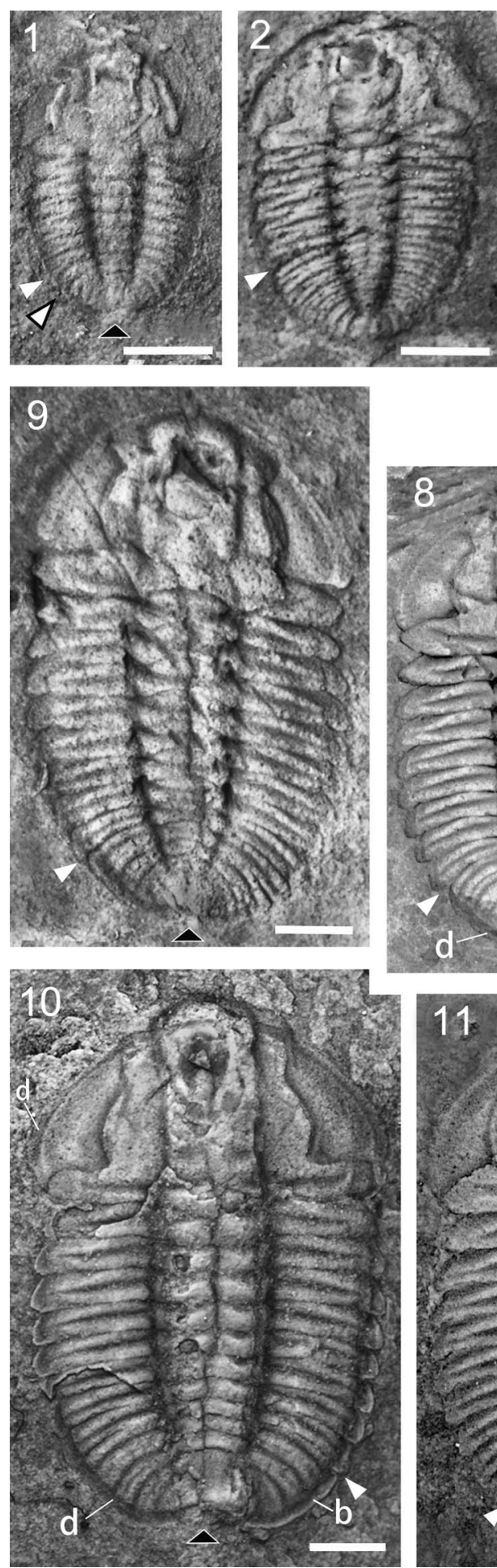
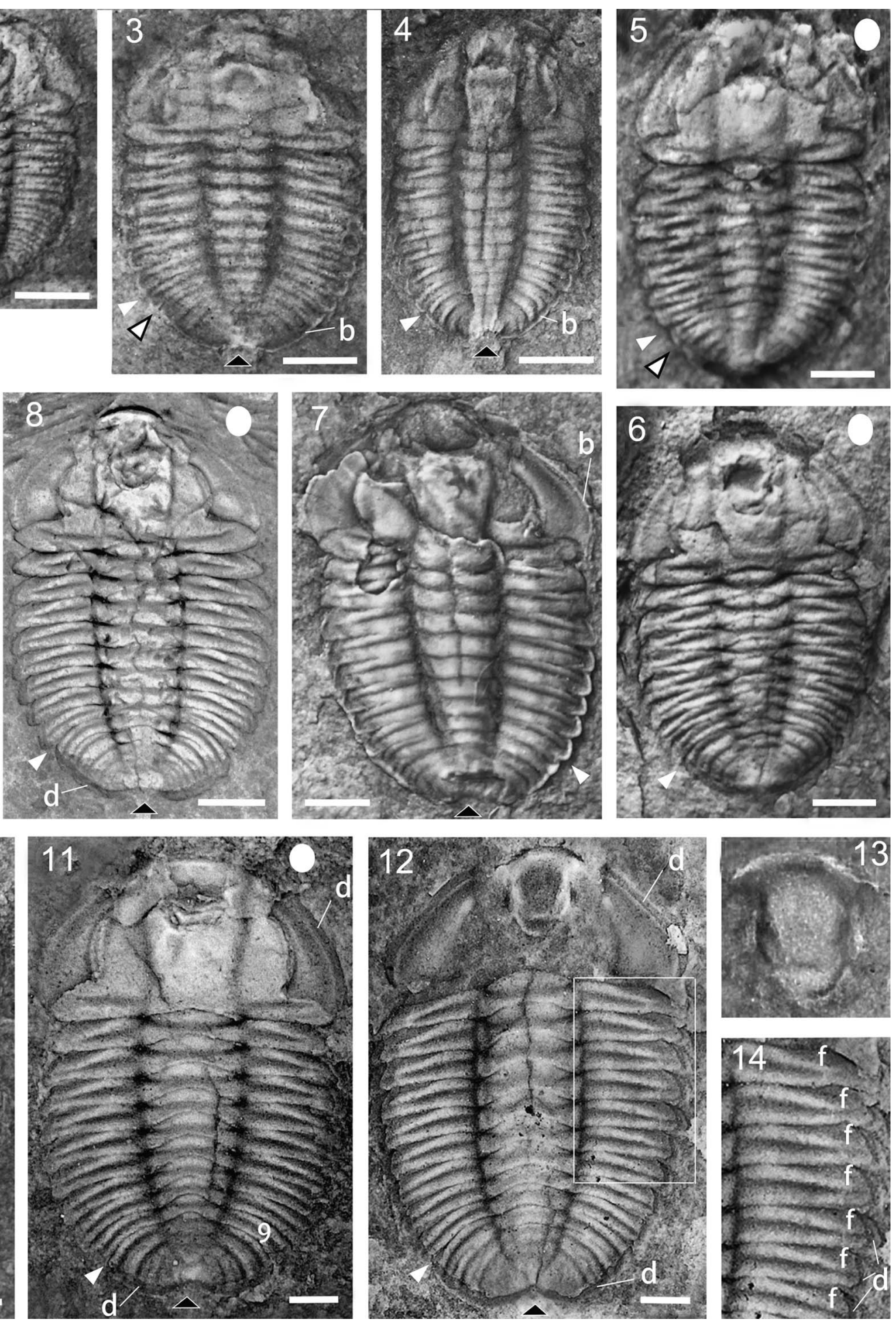

Figure 10. Duyunaspis duyunensis Zhang and Qian in Zhou et al., 1977 from the Balang Formation at Mozichong (1-10) and Paiwu (11-14), Huayuan, northwestern Hunan, China; all in dorsal view unless stated otherwise. White arrowhead indicates the posterior margin of thorax; arrowhead outlined in black indicates the posterior margin of partially released segment of transitory pygidium; black triangle indicates posteromedial notch in pygidial border; $b=$ border, $\mathrm{d}=$ doublure; $\mathrm{f}=$ facet; 9 = ninth thoracic segment: (1) NIGP 164871, latex cast from external mold of exoskeleton, meraspis degree 6, MZC-2; (2) NIGP 164872, exoskeleton, meraspis degree 5, MZC-2; (3) NIGP 164873, latex cast from external mold of exoskeleton, meraspis degree 7, MZC-1; (4) NIGP 164874, latex cast from external mold of exoskeleton, meraspis degree 8, MZC-1; (5) NIGP 164875, exoskeleton, meraspis degree 7, retrodeformation with inferred strain ellipse, MZC-1; (6) NIGP 164876, exoskeleton, meraspis degree 8, retrodeformation with inferred strain ellipse, MZC-2; (7) NIGP 164877, exoskeleton, meraspis degree 8, MZC-1; (8) NIGP 164878, exoskeleton, meraspis degree 8, retrodeformation with inferred strain ellipse, MZC-2; (9) NIGP 164879, exoskeleton, meraspis degree 8, MZC-1; (10) NIGP 164880, exoskeleton, meraspis degree 8, MZC-2; (11) NIGP 159524, exoskeleton, holaspid, retrodeformation with inferred strain ellipse, XHZA314-12; (12) NIGP 159525, incomplete exoskeleton lacking cranidium, holaspis, XHZB117; (13) enlargement of hypostome of specimen in 12, latex cast, ventral view; (14) enlargement of right side of thorax of specimen in 12, showing fulcra, facets and doublure at the margin of the thoracic segments. All scale bars represent $1.0 \mathrm{~mm}$. 
1982 Duyunaspis duyunensis; Liu, p. 299, pl. 213, fig. 10.

1988 Arthricocephalus chauveaui; Lane et al. (part), p. 555, pl. 1, fig. 4; non pl. 1, figs. 1-3, 5, 6 .

2001a Duyunaspis sp., Zhao et al., p. 180, pl. 1, fig. 3.

2001 Duyunaspis duyunensis; Yuan et al., p. 224, pl. 1, fig. 6.

2006 Duyunaspis duyunensis; McNamara et al., p. 7, pl. 2, figs. 5-18, text-fig. 5.

2014 Duyunaspis duyunensis; Lei and Peng, 2014, p. 354, figs. 3, 5b.

2015 Duyunaspis duyunensis; Peng et al., p. 89, pl. 1, fig. 10.

Holotype.-Incomplete exoskeleton (Zhou et al., 1977, p. 132, pl. 41, fig. 5), NIGP 38228, from the Balang Formation, Palang, Duyun, southeastern Guizhou, China; by original designation.

Diagnosis.—As for the genus.

Occurrence.-From dark-gray calcareous mudstone and shale (weathering yellow-green) in the middle part of the Balang Formation, eastern and southeastern Guizhou, western and northwestern Hunan, South China (Jiangnan Slope Belt); Cambrian Stage 4, Duyunian Stage of the regional stratigraphic scheme.

Description.-The description in McNamara et al. (2006, p. 11-12), which applies to specimens from the protaspid period through meraspid degree 7, is slightly emended here. Apart from additional thoracic segments, the specimens of meraspis degree 8 (with eight thoracic segments) and holaspides (with nine thoracic segments) both resemble the meraspid degree 7 exoskeleton.

Hypostome shield-shape; middle body inflated, divided into a long anterior lobe, and a crescentic posterior lobe by a faint medial furrow; macula deeply incised, located near midlength of the middle body; lateral and posterior border narrow, strongly upturned; anterior wing triangular, with subequal length and width, anterior margin (hypostomal suture?) gently arched forward.

Pygidial border gently upturned, defined by a shallow and broad border furrow. Posterior margin with distinct, broad notch.

Materials.-10 exoskeletons (NIGP 164871-164880).

Remarks.-Based on a large collection of 766 exoskeletons from the Balang Formation at Paiwu, Huayuan, northwestern Hunan, Lei and Peng (2014, p. 355-356) synonymized five earlier described species of Duyunaspis with D. duyunensis. The characters previously used to distinguish the species were regarded by Lei and Peng (2014) as the result of either intraspecific variation or taphonomic alteration. The synonymized species are Duyunaspis guzhangensis Zhou (in Zhou et al., 1977, p. 132, pl. 41, fig. 7); Duyunaspis songtaoensis Qian and Lin (in Zhou et al., 1977, p. 132, pl. 41, fig. 8); Duyunaspis briaris Qian and Lin (in Yin and Li, 1978, p. 445, pl. 156, fig. 4); Duyunaspis obesis Qian and Lin (in Zhang et al., 1980, p. 274, pl. 90, fig. 6); and Duyunaspis laevigatus Qian and Lin (in Zhang et al., 1980, p. 274, pl. 91, figs. 7-9). Duyunaspis briaris and $D$. obesis are objective synonyms because both are based on the same holotype cranidium. The types of all five synonymized species are preserved in greenish-yellow shale or mudstone. Some variation among them is probably the result of intraspecific variation (Lei and Peng, 2014, p. 359, table 1). However, the fossils are mostly flattened and distorted, leading to variation in proportions of the exoskeleton and variation in the expression of axial and glabellar furrows. The glabellar furrows have been either enhanced or nearly obliterated through taphonomic distortion. Glabellar furrow S1, which consists of isolated pits separated from the axial furrows in well-preserved cranidia, may attain a transglabellar extent after taphonomic compaction.

The thorax of Duyunaspis duyunensis has been reported to consist of either eight segments (Zhang and Qian in Zhou et al., 1977, p. 182) or seven segments (McNamara et al., 2006, p. 10) in the holaspid period. Lei and Peng (2014, p. 355), however, showed that the holaspid exoskeleton has as many as nine thoracic segments (Lei and Peng, 2014, fig. 3.10-3.16; Fig. 10.11, 10.12).

Duyunaspis paiwuensis (Lei and Peng, 2014, fig. 4), from the lower part of the Balang Formation at Paiwu, northwestern Hunan, resembles $D$. duyunensis in the overall exoskeleton morphology. Duyunaspis paiwuensis differs from the latter species mainly in having a proportionally broader and shorter cephalon, a narrower and longer glabella, a narrower thoracic axis (narrower than the pleural region), and a fulcrum that is located further abaxially from the axial furrow.

\section{Acknowledgements}

We thank J. Vannier (Lyon) for providing access to facilities during SP's visit, and Bertrand Lefebvre (Lyon) for preparing the latex cast of the Bergeron's slab. We thank P.D. Lane (Keele) for recalling information about the preparation of his coauthored 1988 paper; Y. Li (Nanjing) for offering collection LYX-1; I.V. Korovnikov (Novosibirsk) for providing images of topotypic specimens of Oryctocarella sibirica; S. Clausen (Lille) for improving the English translation of Bergeron's (1899) paper; and T.V. Pegel (Novosibirsk) for access to Russian literature. We are also greatly indebted to J. Jago (Adlaide) and G. Geyer (Würzburg) for their helpful comments and suggestions for improving the manuscript, and to B. Hunda (Cincinnati), and N. Hughes (Riverside) for their accurate editorial work. Funding was provided by the National Natural Science Foundation of China to SP (41330101, 41521061, 41290260) and to XZ (41672002), by the Ministry of Science and Technology of China (2015FY31010), and by Regional Geological Survey of Guizhou Province (12120114068201); a grant was provided by the Subsurface Energy Research Center, The Ohio State University to LEB.

\section{References}

Beecher, C.E., 1897, Outline of a natural classification of the trilobites: American Journal of Sciences, Series 3, v. 46, p. 142-147.

Bergeron, J.N., 1899, Étude de quelques trilobites de Chine: Bulletin de la Société Géologique du France, Series 3, v. 27, p. 499-516.

Blaker, M.R., 1986, Notes on the trilobite fauna of the Henson Gletscher Formation (Lower Cambrian) of the central North Greenland: Grønlands Geologiske Undersøgelse, Report 132, p. 65-73.

Blaker, M.R., and Peel, J.S., 1997, Lower Cambrian trilobites from North Greenland: Meddelelser om Grønland, Geoscience, v. 35, 145 p. 
Chernysheva, N.E., 1962, Cambrian trilobites of the family Oryctocephalidae: Trudy Nauchno-issledovatel'skogo Instituta Geologii Arktiki (NIIGA), v. 127, p. 3-64. [in Russian].

Chernysheva, N.E., 1971, The Amgan Stage in the Altay-Sayan region: Trudy Sibirskogo Nauchno-Issledovatelskogo Instituta Geologii, Geofiziki i Mineral'nogo Syrya (SNIIGGiMS), v. 111, 267 p. [in Russian].

Egorova, L.I., Xiang, L.-W., Li, S.-J, Nan, R.-S., and Guo, Z.-M., 1963, The Cambrian trilobite faunas of Guizhou and western Hunan: Institute of Geology and Mineral Resources (Beijing), Special Paper, Series B, Stratigraphy and Palaeontology No. 3,117 p. [in Chinese].

Fletcher, T.P., 2003, Ovatoryctocara granulata: the key to a global Cambrian stage boundary and the correlation of the olenellid, redlichiid and paradoxidid realms: Special Papers in Palaeontology 70, p. 73-102.

Geyer, G., 2005, The base of a revised Middle Cambrian: are suitable concepts for a series boundary in reach?: Geosciences Journal, v. 9, p. 81-99.

Geyer, G., and Peel, J.S., 2011, The Henson Gletscher Formation, North Greenland, and its bearing on the global Cambrian Series 2-Series 3 boundary: Bulletin of Geosciences, v. 86, p. 465-534.

Hupé, P., 1953, Classification des Trilobites: Annales de Paléontologie, v. 39, p. $61-168$.

ICZN, 1999, International Code of Zoological Nomenclature, 4th Edition: London, The International Trust for Zoological Nomenclature, $306 \mathrm{p}$.

Ju, T., 1983, Early Cambrian trilobites from the Hotang and Dachenling formations of Zhejiang: Acta Palaeontologica Sinica, v. 22, p. 628-638. [in Chinese with English abstract].

Khalfin, L.L., ed., 1960, Palaeozoic Biostratigraphy of of the SayanAltay Mountain Range, volume 1, Lower Palaeozoic: Trudy Sibirskogo Nauchno-Issledovatelskogo Instituta Geologii, Geofiziki i Mineral'nogo (SNIIGGiMS) Syrya 19, 498 p. [in Russian].

Kobayashi, T., 1935, The Cambro-Ordovician formations and faunas of South Chosen, Palaeontology Part 3. Cambrian faunas of South Chosen with a special study on the Cambrian trilobite genera and families: Journal of the Faculty of Science, Imperial University of Tokyo, Section II, v. 4, p. 49-344.

Kobayashi, T., 1942, On the Dolichometopinae: Journal of the Faculty of Science, Imperial University of Tokyo, Section II, v. 6, p. 141-206.

Korovnikov, I.V., and Novozhilova, N.V., 2017, Middle Cambrian trilobites from the vicinity of Dolgii Mys Mountain (Khakassia, Batenevsky Ridge): Paleontological Journal (English edition), v. 51, p. 264-272.

Korovnikov, I.V., and Shabanov, Y.Y., 2008, Trilobites from boundary rocks of Lower-Middle Cambrian stratotype section on Molodo River (east of the Siberian Platform), in Budnikov, I.V., ed., Cambrian Sections of the Siberian Platform-Candidates for Stratotypes of Subdivisions of the International Stratigraphical Scheme (Stratigraphy and Palaeontology): Materials for 13th International Field Conference of the Cambrian Stage Subdivision Working Group: Novosibirsk, Siberian Branch of Rusian Academy of Sciences, 120 p. [in Russian].

Lane, P.D., Blaker, M.R., and Zhang, W.-T., 1988, Redescription of the Early Cambrian trilobite Arthricocephalus chauveaui Bergeron, 1899: Acta Palaeontologica Sinica, v. 27, p. 553-560. [in Chinese with English summary].

Lei, Q.-P., 2013, Cambrian trilobites from the the Balang Formation, northwestern Hunan and the Chaomitian Formation, northern Anhui: the faunal features and biostratigraphy [Ph.D. dissertation]: Beijing, University of Chinese Academy of Sciences, $309 \mathrm{p}$.

Lei, Q.-P., 2016, Restudy on Arthricocephalus chauveaui Bergeron, 1899 from the Qiandongian of northwestern Hunan: Geological Journal of China Universities, v. 22, p. 494-501. [in Chinese with English abstract].

Lei, Q.-P., and Peng, S.-C., 2014, Duyunaspis Zhang and Qian in Zhou et al., 1977 (Trilobita) from the Balang Formation (Cambrian, Qiandongian) in northwestern Hunan Province and its interspecific variations: Acta Palaeontologica Sinica, v. 53, p. 352-362. [in Chinese with English abstract].

Liu, Y.-R., 1982, Trilobita, in Li, S.-Q., ed., Palaeontological Atlas of Hunan. Ministry of Geological and Mineral Resources, People's Republic of China, Geological Memior, Series 2, v. 1: Beijing, Geological Publishing House, p. 290-347. [in Chinese].

Lu, Y.-H., 1957, Trilobita, in Institute of Geology and Palaeontology, Academia Sinica, ed., Index Fossils of China, Invertebrate, III: Beijing, Geological Publishing House, p. 249-294. [in Chinese].

Lu, Y.-H., and Qian, Y.-Y., 1964, Cambrian Trilobita, in Wang, Y., ed., A Handbook of Index Fossils from South China: Beijing, Science Press, p. 26-39. [in Chinese].

Lu, Y.-H., Zhu, Z.-L., and Qian, Y.-Y., 1962, Cambrian trilobites, in Wang, Y., ed., A Handbook of Index Fossils from the Yangtze Region: Beijing, Science Press, p. 25-35. [in Chinese].

Lu, Y.-H., Qian, Y.-Y., and Zhu, Z.-L., 1963, Trilobites: Beijing, Science Press, 186 p. [in Chinese].

Lu, Y.-H., Zhang, W.-T., Zhu, Z.-L., Qian, Y.-Y., and Xiang, L.-W., 1965, Trilobites of China: Beijing, Science Press (2 volumes), 766 p. [in Chinese]
Lu, Y.-H., Zhang, W.-T., Qian, Y.-Y., Zhu, Z.-L., Lin, H.-L., Zhou, Z.-Y., Qian, Y., Zhang, S.-G., and Wu, H.J., 1974, Cambrian trilobites, in Nanjing Institute of Geology and Palaeontology, ed., A Handbook of the Stratigraphy and Palaeontology of Southwest China: Beijing, Science Press, p. 82-107. [in Chinese].

Ma, H.-T., Peng, J., Zhao, Y.-L., Da, Y., and Sun, H.-J., 2011, Discovery of the Balang fauna at Luojiatang, Yangqiao, Cengong, Guizhou and its significance to the early evolution of Metazoa: Geological Review, v. 57, p. 743-748. [in Chinese with English abstract].

McNamara, K.J., Yu, F., and Zhou, Z.-Y., 2003, Ontogeny and heterochrony in the oryctocephalid trilobite Arthricocephalus from the early Cambrian of China: Special Papers in Palaeontology, v. 70, p. 103-126.

McNamara, K.J., Yu, F., and Zhou, Z.-Y., 2006, Ontogeny and heterochrony in the early Cambrian oryctocephalid trilobites Changaspis, Duyunaspis and Balangia from China: Palaeontology, v. 49, p. 1-19.

Naimark, E., Shabanov, Y.Y., and Korovnikov, I.V., 2011, Cambrian trilobite Ovatoryctocara Tchernysheva, 1962 from Siberia: Bulletin of Geosciences, v. 86, p. $405-422$.

Peng, J., Zhao, Y.-L, Wu, Y.-S., Yuan, J.-L., and Tai, T.-S., 2005a. The Balang Fauna-a new early Cambrian Fauna from Kaili City, Guizhou Province: Chinese Science Bulletin (English Edition), v. 50, p. 1159-1162.

Peng, J., Zhao, Y.-L, Wu, Y.-S., Yuan, J.-L., and Tai, T.-S., 2005b. Discovery of Balang Fauna of Early Cambrian from Kaili, Guizhou, China: Chinese Science Bulletin (Chinese Edition), v. 50, p. 1055-1057. [in Chinese].

Peng, J., Zhao, Y.-L, and Yang, X.-L., 2006, Trilobites of the upper part of Lower Cambrian Balang Formation, southeastern Guizhou Province, China: Acta Palaeontologica Sinica, v. 45, p. 235-242. [in Chinese with English abstract].

Peng, S.-C., 2000, A new chronostratigraphic subdivision of Cambrian for China: Instituto Superior de Correlación Geólogica (INSUGEO), Miscelánea, v. 6, p. 119-122.

Peng, S.-C., Babcock, L.E., and Cooper, R.A., 2012, The Cambrian Period, in Gradstein, F.M., Ogg, J.G., Schmitz, M.D., and Ogg. G.M., eds., The Geologic Time Scale 2012 (2 volumes): Amsterdam, Elsevier BV, p. $437-488$.

Peng, S.-C., Zhu, X.-J., Babcock, L. E., and Korovnikov, I.V., 2015, Restudy on the genus Arthricocephalus: concept and synonyms: Guizhou Geology, v. 32, p. 83-89. [in Chinese with English abstract].

Qian, Y.-Y., 1961, Cambrian trilobites from Sandu and Duyun, southern Kweichow: Acta Palaeontologica Sinica, v. 9, p. 91-129. [in Chinese with English summary].

Rasetti, F., 1959, Family Oryctocephalidae Beecher, 1897, in Moore, R.C., ed., Treatise on Invertebrate Paleontology, Part O, Arthropoda 1: Boulder, Colorado and Lawrence, Kansas, Geological Society of America and University of Kansas Press, p. O219-O220, O524.

Reed, F.R.C., 1910, The Cambrian fossils of Spiti: Memoirs of the Geological Survey of India, Palaeontologia Indica, series 15, v. 7, p. 1-70.

Saito, K., 1934, Older Cambrian Trilobita and Conchostraca from northwestern Korea: Japanese Journal of Geology and Geography, v. 11, p. $211-237$.

Semashko, A.K., 1969, New Middle Cambrian trilobites from the sandstoneshale suite in the region of the Julie Mine (Batenevsky Mountain Range): Izvestiya Tomskogo Krasnogo Znameni Politekhnicheskogo Instituta Imeni S.M. Kirova, v. 196, p. 71-76. [in Russian].

Shabanov, Y.Y., Korovnikov, I.V., Pereladov, V.S., and Fefelov, A.F., 2008 , Excursion 1a. The traditional Lower-Middle Cambrian boundary in the Kuonamka Formation of the Molodo River section (the southeastern slope of the Olenek Uplift of the Siberian Platform) proposed as a candidate for GSSP of the lower boundary of the Middle Cambrian and its basal (Molodian) stage, defined by the FAD of Ovatoryctocara granulata, in Rozanov, A.Y., and Varlamov, A.I., eds., The Cambrian System of the Siberian Platform. Part 2: North-East of the Siberian Platform: Moscow and Novosibirsk, PIN RAN, p. 8-59.

Shen, Z., Peng, J., Wen, R.-Q., and Liu, S., 2016, Arthricocephalites (trilobite) from the Cambrian and its stratigraphic significance: Acta Palaeontologica Sinica, v. 55, p. 9-18. [in Chinese with English abstract].

Shergold, J.H., 1969, Oryctocephalidae (Trilobita: Middle Cambrian) of Australia: Bulletin, Bureau of Mineral Resources Geology and Geophysics, Australia, v. 104, 66 p.

Suvorova, N.P., 1964, Corynexochoid trilobites and their evolutionary history: Trudy Paleontologicheskogo Instituta, v. 103, 319 p. [in Russian].

Tomashpolskaya, V.D., and Karpinski, R.B., 1961, Some Middle Cambrian trilobites from the region of the village Sukhaya Erba (Batenevsky Ridge): Izvestiya Tomskogo Polytekhnicheskogo Instituta, v. 120, p. 152-160. [in Russian].

Whittington, H.B., 1995, Oryctocephalid trilobites from the Cambrian of North America: Palaeontology, v. 38, p. 543-562.

Whittington, H.B., 1997, Morphology of the exoskeleton, in Kaesler, R.L., ed., Treatise on Invertebrate Paleontology, Part O, Arthropoda 1, Trilobita 
(Revised): Boulder, Colorado and Lawrence, Kansas, Geological Society of America and University of Kansas Press, v. 1, p. O1-O85.

Whittington, H.B., and Kelly, S.R.B., 1997, Morphological terms applied to trilobite, in Kaesler, R.L., ed., Treatise on Invertebrate Paleontology, Part O, Arthropoda 1, Trilobita (Revised): Boulder, Colorado and Lawrence, Kansas, Geological Society of America and University of Kansas Press, v. 1, p. O313-O329.

Yin, G.-Z., and Li, S.-J., 1978, Trilobita, in Working Group of Guizhou Province on Stratigraphy and Palaeontology, ed., Palaeontological Atlas of Southwest China. Guizhou Volume (1), Cambrian-Devonian: Beijing, Geological Publishing House, 843 p. [in Chinese].

Yuan, J.-L., Zhao, Y.-L., and Li, Y., 2001, Notes on the classification and phylogeny of oryctocephalids (Trilobita: Arthropoda): Acta Palaeontologica Sinica, v. 40 (Supp) p. 214-226.

Yuan, J.-L., Zhao, Y.-L., Li, Y., and Huang, Y. -Z., 2002, Trilobite Fauna of the Kaili Formation (uppermost Lower Cambrian-lower Middle Cambrian) from Southeastern Guizhou, South China: Shanghai, Shanghai Science and Technology Press, 423 p. [in Chinese].

Yuan, J.-L., Zhao, Y.-L., and Yang, X.-L., 2006, Speciation of the genus Arthricocephalus Bergeron, 1899 (Trilobita) from the late early Cambrian and its stratigraphic significance: Progress in Natural Science, v. 16, p. 614-623.

Yuan, J.-L., Zhao, Y.-L., Peng, J., Zhu, X.-J., and Lin, J,-P., 2009, Cambrian trilobite Ovatoryctocara granulata Tchernysheva, 1962 and its biostratigraphic significance: Progress in Natural Science, v. 19, p. 213-221.

Zhang, Q.-Z., and Zhou, Z.-M., 1985, Early Cambrian trilobite fauna of Kunshan, Jiangsu: Acta Palaeontologica Sinica, v. 24, p. 259-266. [in Chinese with English abstract].

Zhang, W.-T., Yuan, K.-X., Zhou, Z.-Y., Qian, Y.-Y., and Wang, Z.-Z., 1979, Cambrian of Southwest China, in Nanjing Institute of Geology and
Palaleontology, ed., Carbonate Biostratigraphy of Southwest China: Beijing, Science Press, 336 p. [in Chinese].

Zhang, W.-T., Lu, Y.-H., Zhu, Z-L., Qian, Y.-Y., Lin, H.-L., Zhou, Z.-Y., Zhang, S.G., and Yuan, J.-L., 1980, Cambrian trilobite faunas of southwestern China: Palaeontologia Sinica, New Series B, v. 16, 497 p. [in Chinese with English summary].

Zhao, Y.-L., Yu, Y.-Y., Yuan, J.-L., Yang, X.-L., and Guo, Q.-J., 2001a. Cambrian stratigraphy at Huanglian, Guizhou Province, China: reference section for bases of the Nangaoan and Duyunian stages: Palaeoworld, v. 13, p. $172-181$.

Zhao, Y.-L., Yuan, J.-L., and McCollum, L.B., 2001b. A potential GSSP for the Lower and Middle Cambrian boundary near Balang Village, Taijiang County, Guizhou Province, China: Acta Palaeontologica Sinica, v. 40, supplement, p. 30-142.

Zhao, Y.-L., Yuan, J.-L., Peng, S.-C., Guo, Q.-J., Zhu, L.-J., Peng, J., and Wang, P.-L., 2004, Proposal and prospects for the global Lower-Middle Cambrian boundary: Progress in Natural Science, v. 14, p. 1034-1039.

Zhou, T.-M., Liu, Y.-R., Meng, X.-S., and Sun, Z.-H., 1977, Trilobita, in Institute of Geological Sciences of Hubei Province et al., eds., Atlas of the Palaeontology of South Central China, Volume 1, Early Palaeozoic: Beijing, Geological Publishing House, 470 p. [in Chinese].

Zhu, Z.-L., 1962, On the occurrence of Palaeolenus in Fengyang, Anhui: Acta Palaeontologica Sinica, v. 10, p. 386-393. [in Chinese with English abstract].

Accepted 2 May 2017 